\title{
A review of Brazilian agro-industrial pig farming systems: environmental impacts and applied anaerobic digestion processes with mineral additives
}

\author{
Uma revisão dos sistemas agroindustriais da suinocultura brasileira: impactos ambientais e \\ processos de digestão anaeróbia aplicados com aditivos minerais \\ Una revisión de los sistemas de cría de cerdos agroindustriales brasileños: impactos ambientales y \\ procesos de digestión anaeróbica aplicados con aditivos minerales
}

Hellen Luisa de Castro e Silva ORCID: https://orcid.org/0000-0002-2318-4303 Federal University of Itajubá, Brazil E-mail: hellen-luisa@hotmail.com

Regina Mambeli Barros ORCID: https://orcid.org/0000-0003-3154-2956 Federal University of Itajubá, Brazil E-mail: remambeli@hotmail.com

Ivan Felipe Silva dos Santos

ORCID: https://orcid.org/0000-0002-7172-2794

Federal University of Itajubá, Brazil

E-mail: ivanfelipedeice@ hotmail.com

Electo Eduardo Silva Lora

ORCID: https://orcid.org/0000-0001-8969-3541

Federal University of Itajubá, Brazil E-mail: electo@unifei.edu.br

Marco Aurélio Kondracki de Alcântara ORCID: https://orcid.org/0000-0001-6884-0696 University of São Paulo, Brazil E-mail: marko@usp.br

Rubenildo Vieira Andrade

ORCID: https://orcid.org/0000-0002-9969-7148

Federal University of Itajubá, Brazil

E-mail: rubenildoandrade@yahoo.com.br

\begin{abstract}
The agro-industrial systems comprise activities which transform raw materials of agricultural, aquacultural, livestock and forestry industries from primary production stages to consumption. Pig farming stands out in national and international markets for agro-industrial processes such as slaughtering and meat processing. Although this sector positively contributes to the economies of several countries, the high flow of waste resulting from implementing integrated production systems has led to serious environmental consequences (e.g., polluted water bodies and Greenhouse Gases - GHGs emissions). Among the treatment methods, anaerobic digestion reduces the organic load of biomass in the absence of oxygen, generating biogas and organic fertilizer. However, there are limitations associated with high $\mathrm{CH}_{4}$ variability and low yield, resulting a minimal and slow implementation in Brazil. Some research has reported the use of mineral additives to optimize the digestion process. This study comprises a bibliographic review of pig farming systems and production models, followed by an analysis on a global scale and environmental consequences. It is also discussed the use of additive minerals which have been applied in anaerobic digestion of swine manure as well as some prospects for global advances with opportunities to mitigate GHGs and bottlenecks. Despite being a promising technology, detailed evaluations of the use of these additives and their implementation in treatment plants must still be carried out in such a way to understand the optimization of such process.
\end{abstract}

Keywords: Pig manure; Environmental management; Digestion anaerobic; Mineral additives.

\section{Resumo}

Os sistemas agroindustriais compreendem atividades de transformação de matérias-primas oriundas da agroindústria, aquicultura, pecuária e silvicultura, desde as etapas primárias de produção até o consumo. A suinocultura se destaca no mercado nacional e internacional pelos processos agroindustriais de abate e processamento de carnes. Embora este setor contribua positivamente para as economias de vários países, o alto fluxo de resíduos resultante da implementação de 
sistemas integrados de produção tem levado a graves consequências ambientais, por ex. corpos d'água poluídos e emissões de gases de efeito estufa (GEEs). Dentre os métodos de tratamento, a digestão anaeróbia reduz a carga orgânica da biomassa na ausência de oxigênio, gerando biogás e fertilizante orgânico. No entanto, existem limitações associadas à alta variabilidade de $\mathrm{CH}_{4}$ e baixo rendimento, tornando a implementação no Brasil mínima e lenta. Algumas pesquisas relatam o uso de aditivos minerais para otimizar o processo de biodigestão. Nosso estudo constitui uma revisão bibliográfica sobre sistemas e modelos de produção de suinocultura, seguida de análise em escala global e suas consequências ambientais. A novidade é que este estudo apresenta o uso de minerais aditivos já aplicados na digestão anaeróbia de suínos e uma discussão sobre as perspectivas de avanços globais com oportunidades de mitigação de GEEs e gargalos. Apesar de ser uma tecnologia promissora, avaliações detalhadas do uso desses aditivos e sua implementação nas estações de tratamento ainda devem ser realizadas de forma a otimizar esse processo.

Palavras-chave: Estrume de porco; Gestão ambiental; Digestão anaeróbica; Aditivos minerais.

\section{Resumen}

Los sistemas agroindustriales comprenden actividades de transformación de materias primas provenientes de las industrias agrícola, acuícola, ganadera y forestal, desde las etapas de producción primaria hasta el consumo. La cría de cerdos se destaca en los mercados nacionales e internacionales de procesos agroindustriales para el sacrificio y procesamiento de carne. Si bien este sector contribuye positivamente a las economías de varios países, el alto flujo de residuos resultante de la implementación de sistemas de producción integrados ha tenido graves consecuencias ambientales, p. Ej. masas de agua contaminadas y emisiones de gases de efecto invernadero (GEI). Entre los métodos de tratamiento, la digestión anaeróbica reduce la carga orgánica de biomasa en ausencia de oxígeno, generando biogás y fertilizante orgánico. Sin embargo, existen limitaciones asociadas con la alta variabilidad del $\mathrm{CH}_{4}$ y el bajo rendimiento, lo que hace que la implementación en Brasil sea mínima y lenta. Algunas investigaciones han informado sobre el uso de aditivos minerales para optimizar el proceso de biodigestión. Nuestro estudio constituye una revisión bibliográfica sobre sistemas de cría de cerdos y modelos de producción, seguida de un análisis a escala global y las consecuencias ambientales. La novedad es que este estudio presenta el uso de minerales aditivos ya aplicados en la digestión anaeróbica de cerdos y una discusión sobre las perspectivas de avances globales con oportunidades para mitigar GEI y cuellos de botella. A pesar de ser una tecnología prometedora, aún se deben realizar evaluaciones detalladas del uso de estos aditivos y su implementación en plantas de tratamiento de manera que se optimice este proceso.

Palabras clave: Estiércol de cerdo; Gestión ambiental; Digestión anaeróbica; Aditivos minerales.

\section{Introduction}

Agribusiness comprises a group of activities which transforms raw materials derived from agriculture, aquaculture, livestock and forestry into products. It involves some industries which convert agricultural raw material into intermediate products for food and non-food purposes (Araújo, 2005). Brazil has a simple management structure between the cultivation of subsistence crops, animal husbandry for producing derivatives, storing and processing products (Costa Filho et al., 2017). Brazilian agribusiness contributes to $21.4 \%$ of the national Gross Domestic Product (GDP), of which 60\% is from the agroindustrial sector, which is responsible for a large part of Brazilian exports (Tooge, 2020; Tejon, 2019).

Pig farming stands out in the Brazilian economy, specially in slaughtering and meat processing agro-industrial processes, which are competitive on national and international scale. For the service sector in the country, the gross domestic product (GDP) of the Agro-industrial Pig Farming System (AIPFS) was US\$ 18.7 billion in 2015, contributing to a financial flow of US\$ 45 billion during the same year (Castro E Silva et al., 2019). The Brazilian stock was 1,720,255 sows with a production of 39,263,964 pigs, resulting US\$18,758 billion for the AIPFS GDP and contributing respectively to creating 126,000 and 923,394 direct and indirect jobs in the country (ABCS, 2016). For the same year, the world production resulted 1.2 trillion pigs, with China as the leader with 696 million heads, followed by the European Union (265.8 million heads), the United States (121.4 million heads), Russia (39.7 million heads) and Brazil (39 million heads) (USDA, 2016).

Although this sector contributes positively to the economic balance of several countries, the intensification of agricultural production over the last decades has generated large amounts of manure concentrated in very specific areas (Clusters), resulting difficulties in operational management due to geographical concentrations and causing negative impacts to the environment. This imbalance coupled with the mismanagement of generated manures result the accumulation of organic pollutants in the soil, leading to the increasing of insect populations and antibiotic-resistant bacteria strains. It also results the 
decomposition of waste in the soil, leading to eutrophication of aquatic bodies due to the production of nitrates and phosphates in the soil, as well as contaminating areas adjacent to production areas. Volatile compounds can also cause adverse effects to the health of local populations in addition to increasing GHG emissions (Pereira et al., 2009; SARGA, 2015). Controlling environmental pollution by managing the generated waste is very important, not only to follow the requirements set by the world's environmental agencies, but also to ensure the well-being of society.

About 1,400 million tons of manure are generated in Europe per year. France has the largest production, totaling 1.4 million t N-NH3 per year, 73 million tons $\mathrm{CO}_{2}$ eq / year, and 4 million tons N per year (Foged et al., 2011; Sutton et al., 2011; EUROSTAT, 2013; SARGA, 2015). The damages are estimated at approximately $€ 4,200$ million per year for acidification in aquatic bodies, $€ 2,900$ million per year for society due to the emission of greenhouse gases (GHGs) and $€ 5,200$ million per year for the environment due to the high $\mathrm{N}$ emissions load in rivers, resulting $€ 12,300$ million per year of environmental impact costs (Martínez and Albiac, 2006; Sutton et al., 2011; Smith and Braathen, 2015; SARGA, 2015).

Manure treatment techniques are important tools to comply with regulations related to nitrate and phosphorus loading in water bodies, which specially are the EU Nitrates (EEC, 1991), EU water frameworks (EC, 2000). They are also recommended as part of the GHGs reduction plan under the Gothenburg Protocol (UNECE, 1999) and the NEC Directive (EC, 2001; Loyon, 2017). Over the past decade, researchers have described some types of waste treatment processes with high concentrations of organic matter. These processes depend on factors such as volume, amount of nutrients, type of operation, location, and available financial resources (Diesel et al., 2002). The systems are represented by different classes, which are preliminary, primary, and tertiary treatment systems and are based on manure handling, recovery treatments, concentration, and nutrients removal (Perdomo et al., 2003). Gaete et al. (2020), also mention the possibility of using agro-industrial residues to produce cellulose, an enzyme used in several processes. Regarding to sludge stabilization, anaerobic and aerobic digestion are the most common methods used in the EU-27. The anaerobic process is most commonly applied in Spain, the United Kingdom, Italy, Finland and Slovakia and is considered a renewable energy source by EU directive 2009/28 / EC for manure treatments, while the second is prevalent in the Czech Republic and Poland (EC, 2009; Kelessidis \& Stasinakis, 2012). Low-cost digesters can be used for the treatment of poultry and cattle wastes with consequent biogas production in Brazil, as shown in the studies conducted by Ribeiro et al. (2018) and Ribeiro et al. (2020).

The anaerobic digestion (AD) process is a complex microbial process of degrading organic matter in an oxygen-free environment and is one of the most efficient methods for treating wastewater or stabilizing solids. The process results in the production of biogas containing 60-70\% $\mathrm{CH}_{4}, 30-40 \%$ carbon dioxide $\left(\mathrm{CO}_{2}\right)$, and trace gases such as nitrogen $\left(\mathrm{N}_{2}\right)$, hydrogen $\left(\mathrm{H}_{2}\right)$, hydrogen sulfide $\left(\mathrm{H}_{2} \mathrm{~S}\right)$, ammonia $\left(\mathrm{NH}_{3}\right)$, and water vapor $\left(\mathrm{H}_{2} \mathrm{O}\right)$, and can be used along with digested sludge as an organic fertilizer. The high production of $\mathrm{CH}_{4}$ promotes its use in the bioenergy field, competing with biomass, as well as with biodiesel. Biogas can be applied directly in combined heat and energy systems (CHPs) and can also replace natural gas after removing the $\mathrm{CO}_{2}$ and $\mathrm{H}_{2} \mathrm{O}$. Wastes containing high concentrations of solids such as manure, sewage sludge, organic fractions of solid urban waste (OFMSW) can be used as raw materials in the process (Andriani et al., 2014; Kleerebezem et al., 2015; Godrat et al., 2018).

The most common method for stabilizing organic matter in manure in Brazil is by using dung and decantation ponds (primary and secondary treatment methods) due to the low maintenance cost and the operational ease. After such process, the substrate is applied as an organic fertilizer in some crops (Kunz et al., 2005). The high investment cost, combined with unfavorable political frameworks and business models result a low dissemination of AD systems in Brazil. However, new technologies have bypassed these problems, adding some value to the generated waste. As a result, some incentive measures for the sector have been implemented over the past few years (Santos et al., 2018). The PROBIOGAS program was implemented between 2013 and 2017 via technical cooperation between the Brazilian and German governments per the German Corporation 
for International Cooperation (Deutsche Gesellschaft for Internationale Zusammenarbeit GmbH - GIZ). This program presented some tools to increase the efficient use of biogas in the country (Brasil, 2016). The National Solid Waste Policy, established by Law No. 12,305 / 2010, and regulated by Decree No. 7,404 / 2010 opened the market to technologies aimed at recovering energy from solid waste in Brazil (Brazil, 2010a; Brazil, 2010b). The National Environment Council resolutions n 375/2006 and 430/2011 defined the criteria for using sewage sludge from effluent treatment stations in agriculture and established standards for eliminating effluents in water bodies. These are normative actions that can be applied to manage residues from pig farming. They also analyze the technical efficiency of the digestion and residue systems, as well as the application of biofertilizers in some soils (BRAZIL, 2006; BRAZIL, 2011, Castro E Silva et al., 2020).

The Brazilian Resolution No. 687 / 2015 is a revision of Brazilian Resolution No. 482 / 2012 and sets out the general conditions for mini-generation and distributed microgeneration systems (DG) of renewable sources. These resolutions also establish some methods to access the electricity distribution and compensation systems, inserting small generating biogas plants, and resulting more accessibility in the market (ANEEL, 2012; ANEEL, 2015). The National Agency of Petroleum and Natural Gas and Biofuels resolution No. 8 / 2015 and resolution ANP No. 685 / 2017 outline the details on biomethane added to the natural gas distribution network, and the specifications for biomethane coming from landfills and sewage treatment stations for vehicular and residential use in Brazil (ANP, 2015; ANP, 2017).

Although these normative acts represent major milestones of $\mathrm{AD}$ technology in the contry, the number of biogas plants and installed capacity are still negligible in Brazil (ANEEL, 2020). This is due to the high cost of implementation and low generated revenues. The percentage of biogas plants using animal waste as feedstock is even lower since the production of biogas varies with the number of animals. A study conducted by Castro e Silva et al. (2020) proved economic feasibility (Net Present Value > 0) by producing 10,468 heads of pig, corresponding to an installed power of $14.69 \mathrm{~kW}$, and energy generation of $102,972.83 \mathrm{kWh}$ for $80 \%$ system operation in an agrobusiness system in the Southern of Minas Gerais State, Brazil. However, it is necessary to stress the influence of variability and low $\mathrm{CH}_{4}$ yields in the process, as well as the high content of water and fibers in pig excrement (Costa et al., 2017; Song et al., 2016; Matulaitis et al., 2015; Jinadasa et al., 2012; Molinuevo et al., 2008).

Some studies have reported increases in the efficiency of AD by adding trace elements derived from active minerals, resulting in more biogas production in function of the microorganic and enzymatic transformation during the entire process (Wilkie et al.,1986; Parawira, 2012; Chai et al., 2013; Cruz Viggi et al., 2014; Liu et al., 2015; Wang et al., 2017). The AD treatment plants must taking into account there are no lacks in trace elements regarding the nutritional needs of the methanogens (Demirel \& Scherer, 2011). This study will analyze the demand and presence of nutrients in excrement for AD processes focusing on pig waste as a feedstock.

Trace elements such as iron $(\mathrm{Fe})$, cobalt $(\mathrm{Co})$, nickel $(\mathrm{Ni})$, copper $(\mathrm{Cu})$, zinc $(\mathrm{Zn})$, selenium $(\mathrm{Se})$, tungsten $(\mathrm{W})$ and molybdenum (Mo), are essential for the growth and propagation of microorganisms (Demirel and Scherer, 2011). This study aims to disseminate data regarding the production of pig manure wastes in Brazil and other countries, focusing on possible applications of AD systems in pig farming. It is also analyzed the historical characteristics of agro-industrial systems, the levels of pig farming production worldwide, environmental consequences of pig farming, ideal conditions of some variables in $\mathrm{AD}$ systems, prospects for global advances, limitations and advantages of optimizing AD systems by using mineral additives focusing on pilot scale project and agro-industrial projects.

\section{Methodology}

The methodology applied consists of a review of ascending topics in the literature involving pig production and the use 
of waste manure as feedstock in AD process, following the model of literature review established by Callahan (2010). For this, 122 manuscripts were reviewed to obtain an integrative study involving the world production of pigs and the main Brazilian production systems, as well as the application of AD process as a treatment method, optimization processes, bottlenecks, and future perspectives concerning to global advances and new perspectives, specially in brazilian market. The data and discussions were developed based on researches available in the Web of Science and Academic Google search engines utilizing "Pig farming systems", "Manure", "Anaerobic digestion", "Trace elements", and "Greenhouse gas emissions" as main keywords combinations. The authors based this study on recent works published in literature from the last decade, however some studies from the end of the $20^{\text {th }}$ century are also reported in this paper. Recent data (2016-2018) of Mapping of Brazilian pig farming, Brazilian Pork Producing and Exporting Industry Association, Brazilian Animal Protein Association, and Brazilian National Electric Energy Agency reports have also been discussed in this research.

The swine production has grown worldwide, with pork being the most consumed meat in the world (FAO, 2014a; BBC, 2019). However, high generations of manure have also been reported, especially in some producing countries, resulting in accumulation of nutrients in the soil and water bodies, as well as the emissions of greenhouse gases (GHGs), and odors to atmosphere (Curnow, 2021). As a treatment method, the $\mathrm{AD}$ is an outstanding process, since it can reduce GHGs and high percentage of manure patoghens (EPA, 2014). Furthermore, the process generates biogas, a renewable source, and a substrate as a sideproduct, which can be used as an organic fertilizer in agriculture (EU, 2020). Although the generation of revenue for the system depends on the number of pigs heads, high investment costs and inadequate business models result in few biogas plants installed in the country (Castro e Silva et al., 2021, Santos et al., 2018). Furthermore, some studies report high water and fiber contents might result in varied $\mathrm{CH}_{4}$ yields, hindering the stability of power generation (Costa Filho et al., 2017; Song et al. 2016). Alternatively, the use of trace elements from active minerals have been reported in literature, resulting in higher biogas production and $\mathrm{CH}_{4}$ yields. In this way, such study also composes a review of recent researches about the use of mineral additives to optimize $\mathrm{AD}$ process, focusing especially on updated studies using pig manure as a feedstock in such systems.

\section{Worldwide Pig Farming Production}

The global meat production has increased due to globalization, population growth, and income growth. Pork is currently the most consumed meat in the world (36\% of all worldwide meat consumption) followed by poultry and beef (35\% and $22 \%$, respectively). It is also reported that rich countries have higher meat consumption, while middle-income countries drive demand (FAO, 2014a; BBC, 2019).

In 2018, worldwide pig farming production resulted 1,269,268,000 heads. China has the largest production with 683.86 million heads, followed by the EU - 28 (270 million heads), the USA (133.34 million heads), Brazil (40.95 million heads), Russia (45.25 million heads), and Canada (28.13 million heads) (FAO, 2019a). China has the double production of heads when compared to the EU -28 , and five times the production of USA. The Figure 1 shows the production of the main producing countries between 1960 and 2018 . 
Figure 1 - Main pig producing countries between 1960 and 2018.

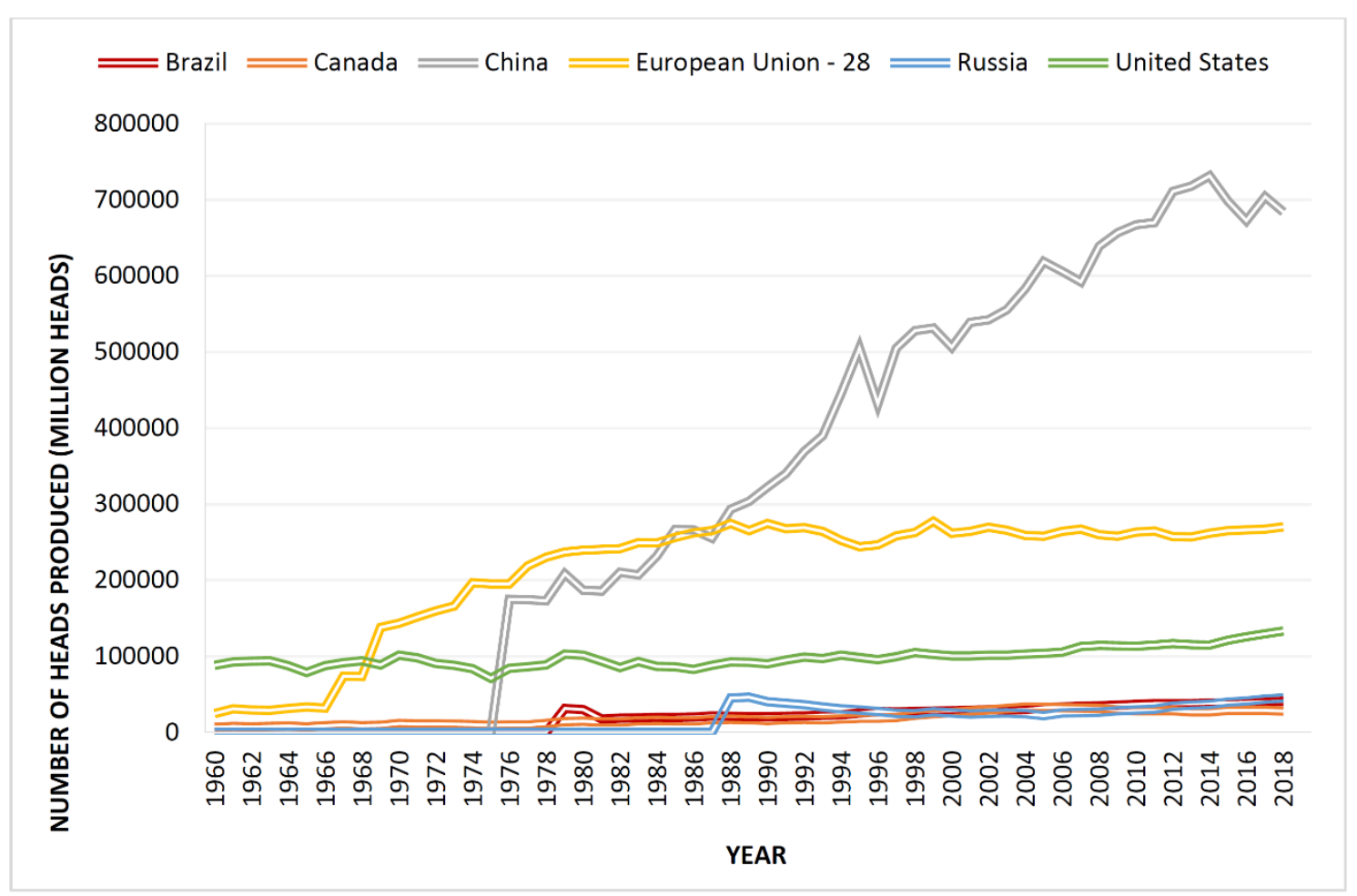

Source: FAO (2019a).

China is the largest producer and consumer of pork in the world, accounting about half of global production (49.7\%) and consumption (50.7\%). Due to cultural traditions, pork constitutes approximately $65 \%$ of the country's animal protein consumption (USITC, 2014). The country's production system is similar to the American industrial model, concentrated and "closer" to industry, and can be characterized into three phases. The first phase occurred after an increase in the animal feed trade and lower import restrictions in the 1980s. The second and third phases were characterized by the country's acceptance into the World Trade Organization (WTO) and the encouragement of production policies at scale, as well as the standardization of pig and industrial production stages, resulting in an increase in production and a reduction in the "backyard farm" model (ABCS, 2016). The most part of chinese production is destined for domestic consumption, but the country exported around 1.620 thousand tons of pork in 2017 (Guimarães et al., 2017; ABPA, 2018). It is also the fifth largest exporter in the world, counting 208 thousand tons, behind the EU - 28 (2,857 tons), the USA (2,555 tons), Canada (1,324 tons) and Brazil (697 tons) (ABPA, 2018).

As the $2^{\text {nd }}$ largest producer, the EU (European Union) - 28 produced 270,000 million heads of pigs in 2018. Spain leads the rankings at 30,804 million heads, followed by Germany (26,445 million heads), France (13,713 million heads), Denmark (12,642 million heads), the Netherlands (11,934 million heads), and Poland (11,027 million heads) (EUROSTAT, 2019). The production growth remained slow over the last decade due to the global financial crisis in 2008, the adoption of new animal welfare rules, the low prices in the food sector, and the reduction of the value of the Euro in an effort to increase the continent's stagnant consumption (ABCS, 2016). In 2018 the majority of imports from this block came from Switzerland (19,000 tons), Serbia (3,600 tons), and Norway (2,702 tons), while the majority of block exports went to East Asia, in particular to China (EC, 2019). In economic terms, livestock production plays a central role in the bloc's agricultural economy, having generated 168 billion Euros in 2014, and resulting $45.5 \%$ of the total value of agricultural production (SARGA, 2015). Furthermore, it is expected that the bloc will maintain the current growth rate, due to environmental and social concerns that will impact its internal 
legislation, coupled with reductions in internal pork consumption. Currently, the bloc exports $12 \%$ of its pork production. After bilateral trade with Russia ended, a large market was closed, increasing supply while lowering demand (Pig Progress, 2016).

In the USA the changes in the organizational structure of the farms after the 1970s caused a slow transition to confined processes, and drove the creation of specialized farms which create the pigs at each stage of their development. This specialization rapidly occurred between 1992 and 2009, resulting in efficiency gains in operational costs and increased specialization and the number production contracts, which increased 65\% in this period (USDA, 2016). The industry acquired pigs ownership, whereas the farmers were responsible for providing farm structure and handling facilities. Another advantage of this transition was the reduction in information asymmetry between pig farmers and industry, improving the quality of agricultural management decisions, access to necessary credit, and agility in transferring technical information (ABCS, 2016).

The largest pig producing states in the USA are located in the "corn belt". The following states have the following production levels.

- Iowa (22,800 heads);

- North Carolina (9,000 heads);

- Minnesota (8,500 heads);

- Illinois (5,350 heads);

- Indiana (4,050 heads);

- Nebraska (3,600 heads);

- Missouri (3,400 heads);

- Ohio (2,950 heads) (USDA, 2018).

American exports receive preferential tariff treatment in some main markets, which some exemptions can be found in Canada and Mexico (North American Free Trade Agreement - NAFTA), and in Korea and Australia, whereas exports to Russia are blocked at this time. The USA exempts both live pork and chilled or frozen meat, as well as imports from countries, while taxes processed pork and countries with bilateral free trade agreements (USITC, 2014). On average, the country's gross revenue is US\$ 20 billion annually, providing around 550,000 jobs, and revenues of US\$ 122 billion from pork slaughtering and processing processes in the states (NPPC, 2019).

Technological advances began in Brazil between 1950 and 1970 focusing on the genetic improvement of the herd, resulting in increased productivity in the 1980s. In 1990, Brazilian slaughterhouses gained greater notoriety in international markets due to high investments in technologies, taking Brazilian industrial pig farming to its current high level, rivaling the best in the world in many aspects. In addition to genetic selection, nutritional management should also be mentioned. This approach focuses not only on productivity, but also on meat quality by taking diet, additives, minerals and vitamins, providing gains in feed conversion and improvements in animal health. Another factor is sanitary control. In this way, the State of Santa Catarina (Southern region of the country) can be stressed as a foot-and-mouth disease free zone. This was achieved even without vaccination programs, according to the World Organization for Animal Health (OIE, 2019). Furthermore, air conditioning at farms results in greater productivity and comfort for the animals, whereas automated facilities reduce labor costs, and expanded capacities and farms specialized in specific production stages (ABCS, 2016).

Besides, it has occured an average increase in the weight of each head of pig. The number of heads slaughtered annually increased from 36.4 million to over 40.7 million (an increase of 12\%) from 2011 to 2016, while production in tons grew 8\%, from 3.36 million to 3.64 million tons, generating revenues in the order of US\$ 43.02 billion (ABIPECS, 2011; ABCS, 2016; ABPA, 2016). During this period, production only dropped in 2013 when the size of the national herd decreased by $5 \%$ after a severe crisis in this sector. At this period, there was a reduction in the production of soybeans and corn in the USA, which led to a increased price for these commodities in the international market and pressured pig production in Brazil (ABCS, 2016). 
Total Brazilian production reached 3.97 million tons in 2018, with 646 thousand tons exported, making the country the $4^{\text {th }}$ largest producer and exporter of pork in the world. When analyzing the production data, the country exported 8.7 million tons, accounting for US\$2.7 billion in revenues in the period from 2004 to 2018 (ABPA, 2018). The southern states lead Brazilian production rankings, accounting for $64 \%$ of slaughtered pigs, followed by the Southeast Regions (20\%), the Midwest (14.8\%), the Northeast $(1.1 \%)$, and the North $(0.1 \%)$ in the $4^{\text {th }}$ quarter of 2019 . The following states had the following production levels (IBGE, 2019).

- Santa Catarina (more than 376.87 thousand slaughtered heads);

- Minas Gerais (more than 132.84 thousand heads stand out);

- São Paulo (more than 85.98 thousand heads);

- Mato Grosso (more than 80.87 thousand heads);

- Goiás (more than 80.25 thousand heads);

- Mato Grosso do Sul (more than 19.68 thousand heads).

Reduced production levels have been observed in the following states (IBGE, 2019)

- Paraná (minus 93.38 thousand heads);

- Rio Grande do Sul (minus 7.00 thousand heads).

For that same year, Brazilian exports resulted 54.4 thousand tons and shipments from the sector generated US\$111.4 million in January. Regarding the impact of foreign markets, even with the embargo on Russia, Brazil increased shipments to China and Hong Kong in 2018. In the beginning of 2018, China and Hong Kong imported 13.5 and 17.2 thousand tons of pork, generating revenue in the order of US\$28.9 million and US\$34.8 million, respectively (ABCS, 2018).

The drop in pig stocks in Russia in beginning of the $21^{\text {st }}$ century was reversed in 2005 due to state support and commercial measures which encouraged meat consumption in the country (FAO, 2014b, GRAY, 2009). Pork production in the Russian Federation grew 49\% in the period from 2005 to 2010, and imports continued to grow at 9\%. Concerning to imported meat in 2010, 22\% was destined mainly for processing activities for supplying the domestic market. Between 2010 and 2012 the country faced high food costs and slowed production, causing producers to reduce stocks (FAO, 2014b). Currently, pork is the second most popular meat in Russia and about $45 \%$ and $23 \%$ of all pork Brazilian are exported to Russia and Hong Kong each year (ABCS, 2016; PPC, 2016). Russia has about 20 major production companies, despite the volume of national production, reaching 4.86 million tons in live weight. Russia expects to increase the number of pork imports, mainly due to increased supply in Brazil (PPC, 2016, 2019a) with US\$ 720 million in 2018 of investments in pig industry, and an expected increase of 200 thousand to 300 thousand tons in exports over the next four years, increasing the production capacity of this country (PPC, 2019b).

In Canada there was a gradual shift from subsistence farming to more commercial farming with specialized farms, resulting in an increase in the average herd size and the expansion of the pig sector from 1921 to 1960. From 1976 to 1981, there was a rapid expansion of pig farming, but high interest rates and the Asian financial crisis led to stagnation until the early 1990s. Canada achieved significant economic growth from 1996 to 2006 stimulated by NAFTA, and the Canadian herd reached approximately 15 million head. There was a decline (around 35.9\%) after that period, due to the fall in prices between 2005 and 2010, the world food crisis in 2008, and droughts in the southern USA and Australia. Canada also stopped imports from China and Russia. Furthermore, the price of a barrel of oil increased, and speculation in the stock market contributed to increased grain prices, the biggest expense item for pig farming.

This price increase strongly affected the profitability of pig farms, which have not yet returned to their previous levels. Despite this, Canada was the $4^{\text {th }}$ largest pig producer worldwide in 2011, with revenues in the order of US\$3.9 billion. The value of Canadian dollar was similar to the value of the US dollar for several years (except in 2009), so Canadian exports were more 
expensive compared to imports. The USA is the largest importer of Canadian pigs, and prices are often influenced by the Chicago Stock Exchange (Statistics Canada, 2014). Market operations are the most common (41.4\%), followed by farrow-to-finish operations (29.4\%), which raise pigs at all stages of their development, until they reach 225-300 pounds. Pig raising for breastfeeding and nursery operations (29.2\%) focus only on birthing and rearing piglets (Statistics Canada, 2014). Currently, the pig industry in Canada adds US\$ 24 billion to the economy, and US\$ 1.2 million of investments are planned by the Canadian government to promote and expand the pork market in the country (Fortune, 2019; Government of Canada, 2019).

\section{The Worldwide Agro-Industrial System and Production Models of Pig Farming in Brazil}

The Agro-Industrial Pig Farming System (AIPFS) in Brazil is comprised of agro-industries (slaughterhouses), distributors (wholesale and retail), farms (animal husbandry), food industries, input producers (equipment, genetics, medicine, feed and vaccines), and final consumers (Santini \& Souza Filho, 2004).

The genetics sector is the first segment strictly related to the production chain, in which the most relevant genetic houses originate from developed countries, which are responsible for improving races or strains, making them more productive and less susceptible to diseases. Besides, some inputs such as soy and corn are essential raw materials for the formulation of animal feed.

The breeding, gestation, reproduction, weaning, fattening phases of production, storage, treatment, and disposal of the waste cover all reproduction and production units. Agribusinesses, wholesalers, retailers, exporters and importers are the final links in the chain, along with transformation industries which processes by-products like leather, meat, bone and blood meal, completing the cycle by delivering final products to internal and external consumers (Guimarães et al., 2017). The Figure 2 shows the layout of a Brazilian AIPFS. 
Figure 2 - Brazilian AIPFS (Agro-Industrial Pig Farming System).

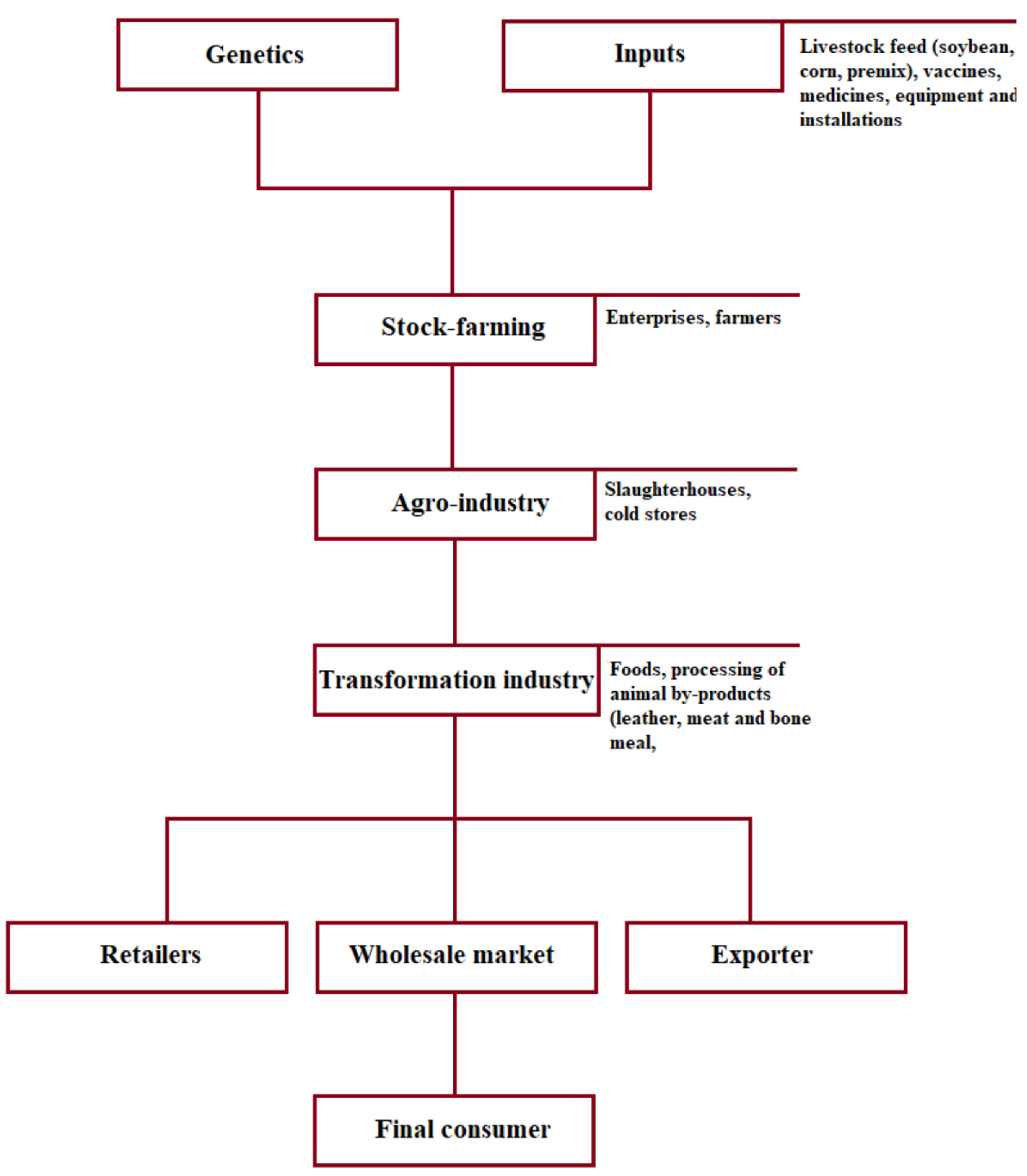

Source: Adapted from Guimarães et al. (2017).

Various organizational forms of the AIPFS are attributed to the production chain, which can consist of small independent producers, regional companies or verticalized production complexes operating in domestic and foreign markets (Santos, 2011; Guimarães, 2017). In Brazil, the origin of these systems arose through small organizational arrangements formed by the arrival of German, Italian, and Portuguese immigrants in the $19^{\text {th }}$ century, contributing to pig farming as an important economic activity, especially in the southeastern and southern regions of the country.

The lard was the main product sold in the country in that century, specially to the oil processing industry. In this way, the production was modified, resulting some modifications in the feeding patterns of pigs and value losses in the "lard type" pig market. These phenomena resulted in changes in the physical structure of the farms, the feeding of animals, and the selection of 
breeds with meat capacity. Management systems significantly increased production costs and gave rise to the first cooperatives, which adopted an integrated livestock industry model, adding greater values to the products (Terhorst \& Schmitz, 2007).

Between the 1960s and 1970s, agricultural credit policies were created along with the first genetic improvement programs in 1977. Examples are the public research company "Embrapa Pig and Poultry", under the Ministry of Agriculture, Livestock and Supply (MAPA), and private sector entities such as "Agroceres", a partner with the English company Pig Improvement Company - PIC. These companies expanded productive borders throughout the national territory, bringing the first genetic nucleus for developing high-performance hybrid pigs in Brazil (Moraes \& Capanema, 2012; Agroceres Pic, 2016).

The full cycle production (CC) predominated until the 1990s, in which all stages of animal production (gestation, maternity, nursery, and termination) were carried out at the same establishment. This independent model system is still used by traditional rural producers who buy inputs and trade pigs with the agro-industry without formal contracts, and are present at different scales in almost all Brazilian states. The producer has ownership of the assets produced, as holds responsibility for the necessary inputs. The producer must also negotiate the final product using predominantly simple purchase and sales contracts with agribusinesses, as shown in the Figure 3 (ABCS, 2016).

Figure 3 - Independent pig production model.

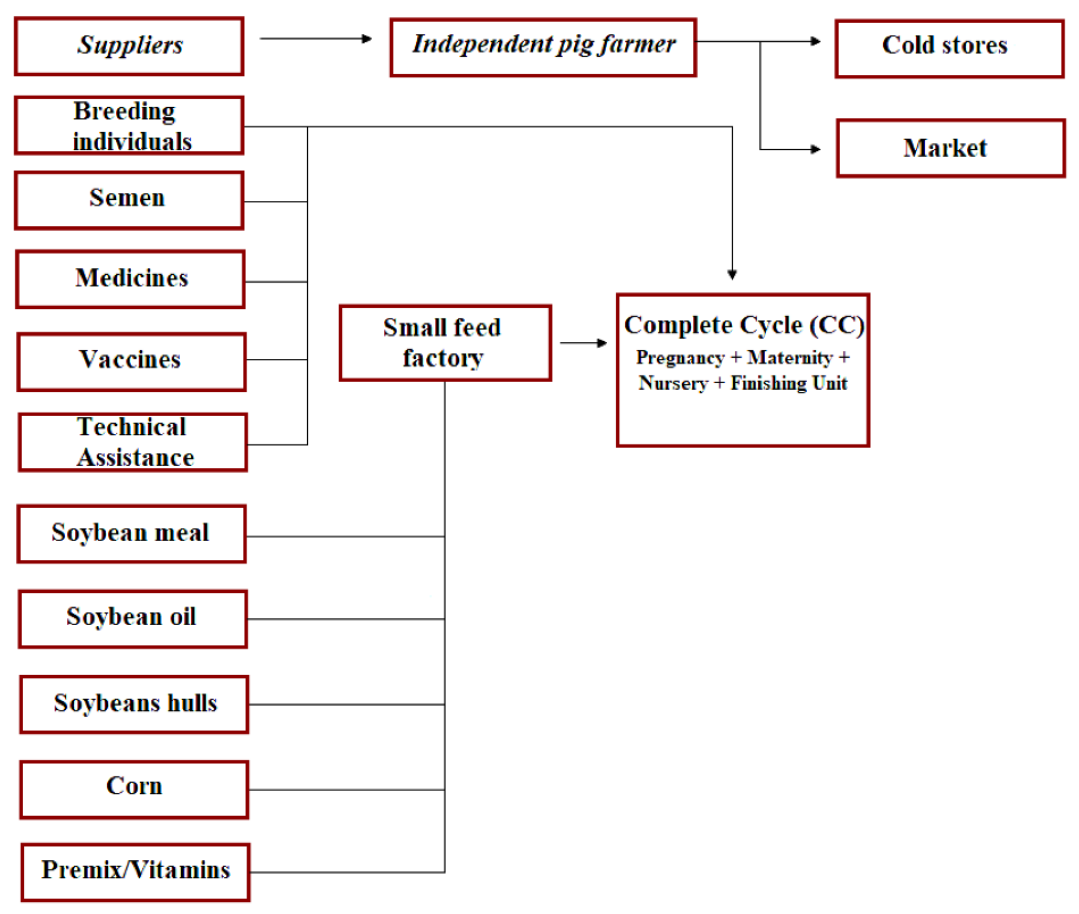

Source: Adapted from ABCS (2016).

The Brazil's large national debt led to cuts in agricultural credits which were accompanied by a drop in the price of soybeans in international market. This created a need for adopting new government management models for the entire sector (Santos, 2011). The integrated production method emerged in the early twentieth century in the state of Santa Catarina, and became popular in the South, being spread throughout the country. A company coordinates the operations and supplies inputs to the integrated producers in the integrated production system, resulting in more specialized systems and specific valuation at each stage, leading to better financial results and meat quality (Santos, 2011). 
The integrated production system is divided into different stages of specialization: nursery and piglet production unit (PPU), weaner production unit (WPU) and finishing unit (FU). These divisions lead to the increasing of production and reduced some establishments (Souza et al., 2013).

The PPU receives weaned piglets, a critical moment in terms of nutritional, health and immunological care. This is an important phase in the specialization of farms, since there is maternal separation, transition from liquid feeding (milk) to feed, transportation, environmental changes, and social conflicts arising from coexistence, reducing piglet immunity. Subsequently, piglets are raised to approximately 22 to $26 \mathrm{~kg}$ and are transferred to FU. The WPU differs from the PPU, since it does not have nursery phase, producing $6 \mathrm{~kg}$ piglets at 21 days, which are sent to nurseries or to wean to finish (WF) farms. The latter is characterized by a production system developed in the USA in the 1990s, and is present in several countries. In this method, the piglets are weaned and sent to a WF where they remain until slaughter. Thus, the system must have its facilities planned to house pigs from $6 \mathrm{~kg}$ to $125-145 \mathrm{~kg}$. In this way, a simplified production and logistics process can be obtained (ABCS, 2016). However, such system demands larger areas and better production conditions.

The integrated production model offers greater security to the producer, allowing production costs to be controlled, obtaining higher productivity rates via specialization, controlling the quality of the necessary inputs according to the receiving market of the final product, optimizing logistical processes, and guaranteeing supply to industries and consumer markets. The integrated production model is an evolution away from traditional production systems. The main economic agent is the agribusiness, which coordinates the main inputs required for production, such as breeders, animals for fattening, and feed. It delegates farm and animal management like breeding stock and piglets to the pig farmer. The Figure 4 shows a schema of integrated production system.

Figure 4 - Integrated pig production system.

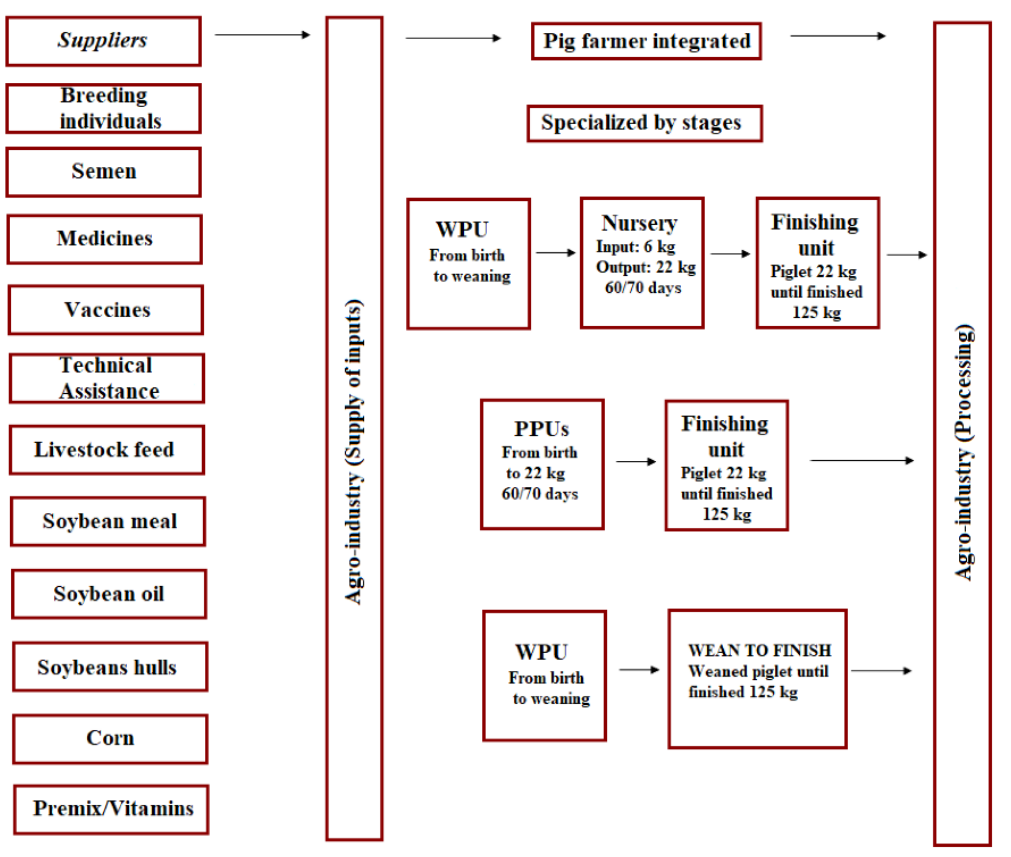

Source: Adapted from ABCS (2016). 
The management system adopted by the pig farmer in cooperatives has cooperative members who share the profits among associates, which will directly depend on the cooperative's assets. Business diversification directly influences the degree of technification on the farm, as well as the production system adopted by the pig farmer. The transactions between pig farmers and cooperatives are similar in terms of the model shown in the Figure 3.

\section{Environmental consequences of Pig Farming and Application of Anaerobic Digestion as a Treatment Method}

In the $19^{\text {th }}$ century, traditional agriculture was based on small facilities, and excrement were used as fertilizers in the soil, whereas animals used to fed on pasture. However, intensive production systems led to an increase in livestock farms, resulting in increased production of cattle heads (Burton and Turner, 2003). As a consequence, large amounts of waste are generated in concentrated areas, leading to an excess of manure that is not used by the local agricultural industry due to the limited agricultural resources available (SARGA, 2015). High generation, combined with accumulation and the indiscriminate use of soils have resulted in the contaminations of soils, waterbodies and pollutants emissions to the atmosphere. The main problems are soil impermeabilization, groundwater contamination, groundwater pollution, accumulation of toxic organisms and elements, acidification by ammonia $\left(\mathrm{NH}_{3}\right)$, salinization of water bodies, emission of greenhouse gases (GHGs), odors, dust and noise (Diesel et al., 2002 and SARGA, 2015).

The AD process is characterized by the decomposition of organic matter in a humid atmosphere in the absence of air (redox potential $<-200 \mathrm{mV}$ ) and in the presence of a group of metabolically active microorganisms (Deublein and Steinhauser, 2008; Kunz et al., 2019). Biogas is produced as a result and is a renewable fuel consisting of a mixture of gases. The digested substrate can also be used as an organic fertilizer after applying solid or liquid separation techniques (Jørgensen, 2009; Maldaner et al., 2018). The energy content of biogas is mainly determined by methane $\left(\mathrm{CH}_{4}\right)$, which ranges from $50 \%$ to $75 \%$, followed by carbon dioxide $\left(\mathrm{CO}_{2}\right)$, with a share between $25 \%$ and $50 \%$, and 2-8\% of trace gases such as water $\left(\mathrm{H}_{2} \mathrm{O}\right)$, nitrogen $\left(\mathrm{N}_{2}\right)$, oxygen $\left(\mathrm{O}_{2}\right)$, sulfur $\left(\mathrm{S}_{2}\right)$, ammonia $\left(\mathrm{NH}_{3}\right)$, and hydrogen sulfide $\left(\mathrm{H}_{2} \mathrm{~S}\right)$ (Costa Gomez, 2013).

The AD process is divided into four phases, hydrolysis, acidogenesis, acetogenesis, and methanogenesis, performed by different microorganisms in syntrophy, which require different environmental conditions (Kunz et al. 2019). The Figure 5 shows the steps in the AD process, which will be further explained. According to Ferreira (2021), pH, temperature, hydraulic retention time, presence of nutrients, solids (total, volatile), BOD and COD are the main factors which will influence in such process (Cruz et al., 2019, Ferreira, 2021). 
Figure 5 - Hydrolysis, acidogenesis, acetogenesis and methanogenesis processes.

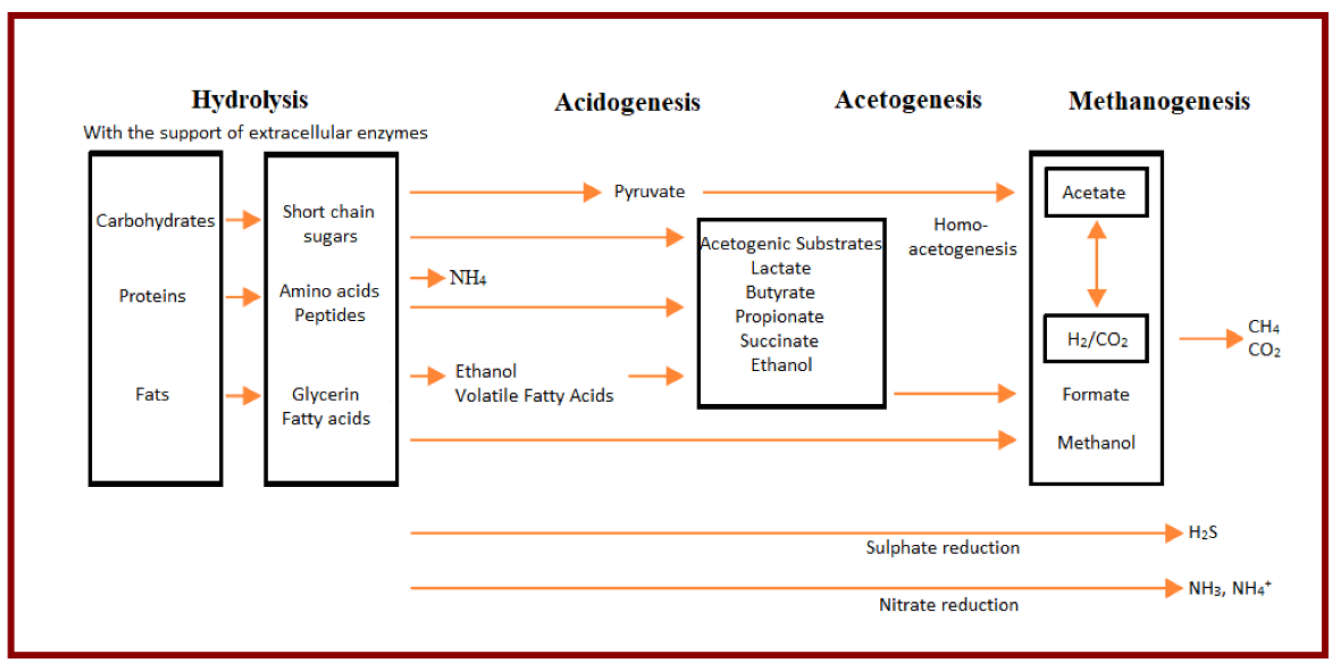

Source: Adapted from Kunz et al. (2019).

\section{Hydrolysis}

This process degrades high polymer chain compounds such as lipids, polysaccharides and proteins into simpler and more soluble organic substances by means of extracellular enzymes, produced by hydrolytic bacteria. The importance of this step in the rate of degradation depends on the characteristic of the substrate, and it can be a limiting step in the speed of AD when the organic matter is complex and difficult to be degraded. In this sense, it takes few hours for carbohydrates degradation, whereas few days for proteins and lipids degradation are necessary in the process (Kunz et al. 2019). The cellulose and hemicellulose molecules are difficult to degrade by specialized bacteria, since they are surrounded by lignin, which are difficult to be synthetized by bacteria. As a result, only $40 \%$ of these molecules in pig excrement are decomposed into biogas. Usually, the concentration of $\mathrm{CH} 4$ varies from 30-60\% for animal excrement and other types of substrates which have high chain complexity (Jørgensen, 2009).

\section{Acidogenesis}

Hydrolyzed substances are used as substrates by anaerobic and facultative bacteria, and are degraded into short chain organic acids such as butyric, propionic, and acetic acids. Partial pressurization using hydrogen during the process directly affects the oxidation state of the products. If higher levels are achieved, the products will have a higher amount of carbon (Kunz et al. 2019).

Carbohydrates, such as glucose, are broken down into pyruvate, which is converted into lactic acid by Lactobacillales and into ethanol by yeasts. Fatty acids are degraded by Acetobacter by $\beta$-oxidation. They must be linked to coenzyme A, and the oxidation process then occurs via a sequential release of two carbon units in the form of acetate. Amino acids are degraded in pairs by Clostridium Botulinum via the Stickland reaction (Figure 6), in which one amino acid acts as a receptor and another as an acceptor. As a consequence, acetate, $\mathrm{NH}_{4}, \mathrm{CO}_{2}$, and $\mathrm{H}_{2} \mathrm{~S}$ are formed (Kunz et al. 2019). 
Figure 6 - Stickland Reaction.

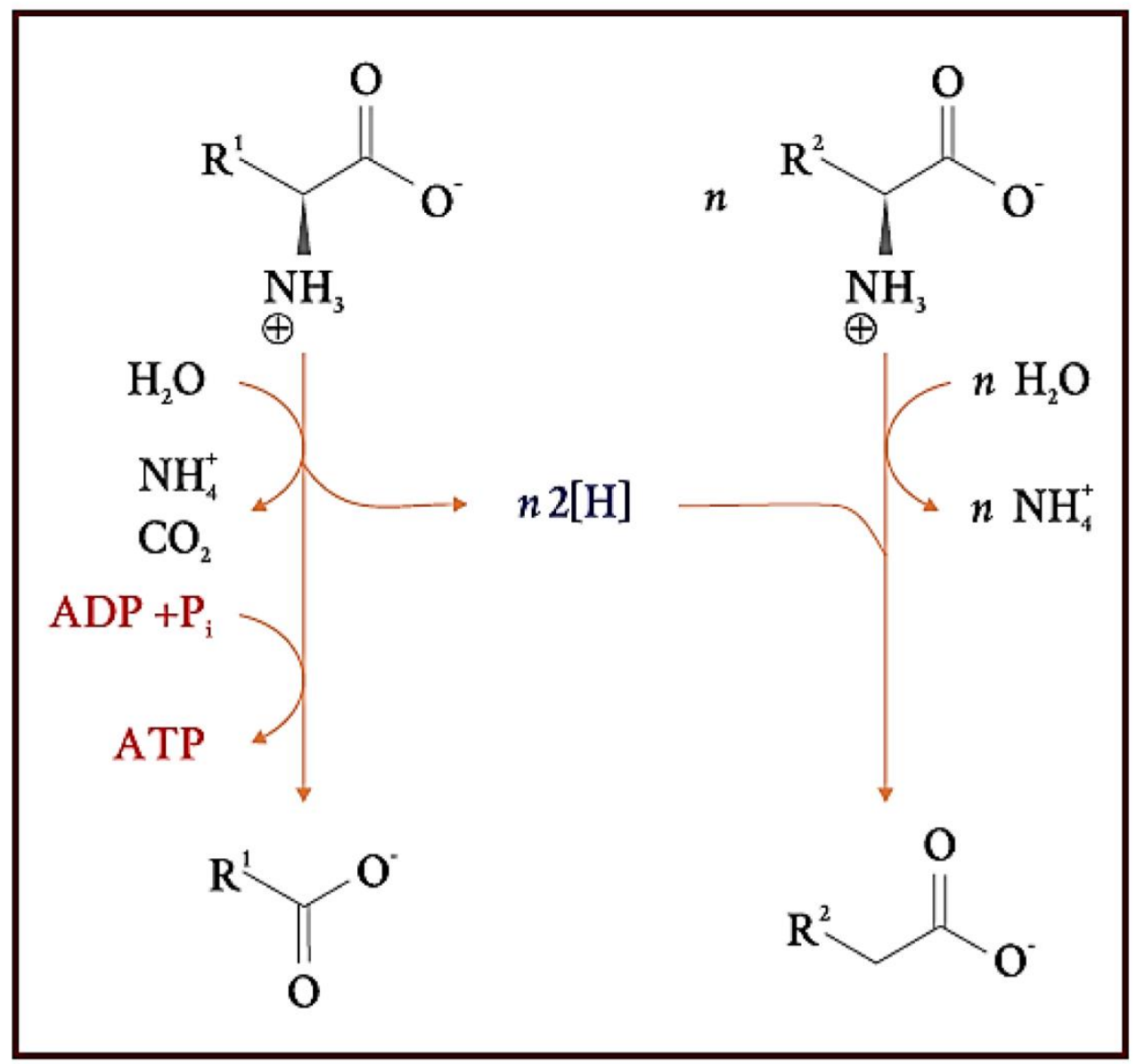

Source: Kunz et al. (2019).

In the bacterial balance process, about $50 \%$ of monomers like glucose, xylose and amino acids, and long-chain fatty acids (LCFA), which have more than nine chain carbons, are decomposed into acetic acid $\left(\mathrm{CH}_{3} \mathrm{COOH}\right)$. Approximately $20 \%$ is converted to $\mathrm{CO}_{2}$ and $\mathrm{H}_{2}$, and the remainder is transformed into short-chain fatty acids (SCFA), which have less than six chain carbons. When an imbalance occurs, the relative level of SCFA will increase with the risk of accumulation, since SCFAdegrading bacteria have a low growth rate, failing to keep up with the constant rate of SCFA degradation. In this context, the production of fatty acids is crucial, becoming a limiting factor for biogas production processes (Jørgensen, 2009).

\section{Acetogenesis}

In this phase, endothermic reactions are conducted by a bacteria called acetogenic, which establishes a syntrophy relationship with methanogenic archaea and homoacetogenic bacteria. Long-chain acids are transformed into lower-chain acids, such as formic and acetic acid, with the parallel production of $\mathrm{H}_{2}$ and $\mathrm{CO}_{2}$. Homoacetogenic bacteria govern the balance of the consumption direction of $\mathrm{H}_{2}$ and $\mathrm{CO}_{2}$ for the production of acetate, as shown in Equation 1. For the thermodynamically favorable formation of short-chain fatty acids, such reaction must occur with the consumption of hydrogen via the methanogenic archaea. The syntrophy between organisms of different groups results in their growth, resulting acetate via organic acids (Kunz et al. 2019).

$$
\mathrm{CO}_{2}+4 \mathrm{H}_{2} \rightleftharpoons \mathrm{CH}_{3} \mathrm{COOH}+2 \mathrm{H}_{2} \mathrm{O}
$$




\section{Methanogenesis}

This stage occurs in strictly anaerobic conditions, in which the carbon present in the biomass is converted to $\mathrm{CO}_{2}$ and $\mathrm{CH}_{4}$ by methanogenic organisms belonging to the Archaea kingdom, part of a taxonomic system that also comprises eukaryotes and bacteria at that level (Jørgensen, 2009).

According to the metabolic pathways, methanogenic archaea are divided into acetoclastic and hydrogenotrophic archaea. Methanosarcina converts acetate to methane and Methanobacterium and Methanospirillum convert $\mathrm{H}_{2}$ and $\mathrm{CO}_{2}$ to $\mathrm{CH}_{4}$ in exothermic reactions (Kunz et al. 2019). The formation of $\mathrm{CH}_{4}$ via acetate or $\mathrm{CO}_{2}$ is shown in Figure 7.

Figure 7 - (a) Formation of methane via acetate; (b) Formation of methane via carbon dioxide. CoA = Coenzyme A; CoM = Coenzyme M.

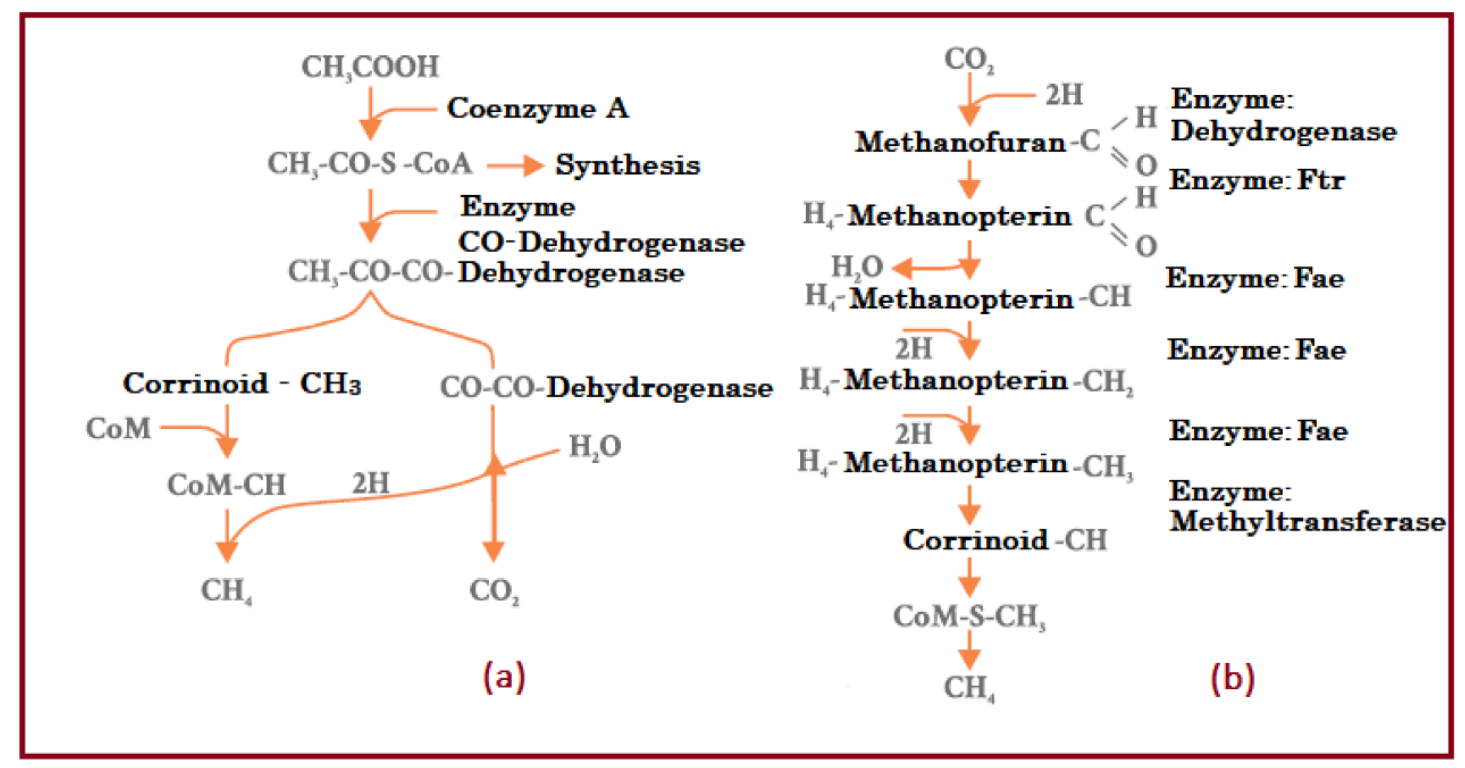

Source: Kunz et al. (2019).

Some authors report a production ratio of $70 / 30 \% \mathrm{CH}_{4}$ between acetoclastic / hydrogenotrophic methanogenic archaea (Jørgensen, 2009). However, other authors indicate this relationship is dynamic. Acetoclastic methanogenic archaea are more sensitive to changes in $\mathrm{pH}$ and high concentrations of $\mathrm{NH}_{4}{ }^{+}$, and characteristic of agricultural substrates, contributing to the predominance of methanogenic hydrogenotrophic archea in these substrates. The produced acetate in the eventual absence of acetoclastic methanogens is oxidized by homoacetogenic bacteria, producing $\mathrm{CO}_{2}$ and $\mathrm{H}_{2}$ (Figure 5), which in turn are used by methanogenic archaea for producing $\mathrm{CH}_{4}$ (Kunz et al. 2019).

Methanogens have the slowest growth rate of bacteria involved in the process, which is also a limiting factor for their speed and for how much material can be digested. The growth of these microorganisms is approximately $1 / 5$ of the acid-forming bacteria. Although they do not release much energy in the process (36-131 energy yield $\mathrm{kJ} / \mathrm{mol}^{\circ} \mathrm{CH}_{4}$ ), competition with sulfate-reducing bacteria (SRB) is limited, due to anoxic conditions, allowing them to survive during the process (Jørgensen, 2009). According to Barton (1995), SBR compete with other anaerobic microorganisms, such as fermenting bacteria (FB), acetogenic bacteria $(\mathrm{AB})$ and methanogenic bacteria $(\mathrm{MB})$ in anaerobic environments with low redox potential, due to the common substrates used by these groups, mainly $\mathrm{H}_{2}$ and acetate. According to Chou et al. (2008), the COD / sulfate ratio results from the competition of SBR and MB. The authors found a maximum 1:1 ratio for the prevalence of SBR in conjunction with MB for acetate as the substrate. 
The use of liquid manure in $\mathrm{AD}$ processes has a high potential for mitigating greenhouse gases (GHGs), since $\mathrm{CH}_{4}$ emissions generally represent more than $95 \%$ of the GHGs emissions generated from manure storage (Maldaner et al., 2018). It is important to capture $\mathrm{CH}_{4}$ and $\mathrm{CO}_{2}$ during this process, since the emissions result in increased absorption of electromagnetic energy, resulting in an increase in the greenhouse effect. The $\mathrm{CH}_{4}$ gas emissions are even more worrying, since this molecule has a greenhouse effect approximately 28 to 36 times greater than $\mathrm{CO}_{2}$. In this way, the AD system implantation can reduce GHG emissions (EPA, 2017; Pagliuso and Regattieri, 2008).

However optimal conditions are needed for biodegradation to be applied, e.g. the absence of oxygen, temperature in mesophilic conditions $\left(\mathrm{T}=35^{\circ} \mathrm{C}\right)$, and an optimal supply of nutrients, $\mathrm{pH}$, recalcitrant elements, antibiotics, macro and micro nutrients, $\mathrm{C} / \mathrm{N}$ ratio, and inhibition by $\mathrm{NH}_{3}$ (Barros, 2012). In addition, it is possible to increase the content of degradable organic matter by adding co-substrates, such as food residues together with manure.

\section{The Use of Mineral Additives to Optimize the Anaerobic Digestion Process in pig Farming Systems}

Some authors have reported support materials applied to biomass with a high organic rate results in improvements in the kinetics of the $\mathrm{AD}$ process, even at low hydraulic retention times (HRT). A COD removal efficiency of $80 \%$ at $25^{\circ} \mathrm{C}$ was used for pig farming industry in reactors with clay material supports, like smectite, saponite, and calcined sepiolite (Arif $e t$ al., 2018). Another study used modified porphyritic andesite as a $\mathrm{NH}_{4}{ }^{+}$adsorbent and bed material for the $\mathrm{AD}$ of ammonium-rich pig residues providing higher $\mathrm{CH}_{4}$ and COD yields and removal rates of approximately $68 \%$ for 44 days under mesophilic conditions (Wang et al., 2012). Aponte-Morales, Tong and Ergas (2016) used particulate chabazite zeolite in a sequential batch reactor (SBR), obtaining nitrification inhibition, combined with denitrification and alkalinity control.

Some studies have also reported an increase in the efficiency of the AD process by adding trace elements derived from active minerals, resulting in higher biogas production, obtained from microorganic and enzymatic transformation in the entire process (Wilkie et al., 1986; Parawira, 2012; Chai et al., 2013; Cruz Viggi et al., 2014; Liu et al., 2015; Wang et al., 2017). To analyze the performance of anaerobic treatment plants, it is necessary to determine if there is a deficiency of trace elements according to the nutritional needs of the methanogens (Demirel \& Scherer, 2011). Research activities about the demand and presence of nutrients in $\mathrm{AD}$ excrement processes are presented in this topic, focusing on studies using pig wastes as feedstocks.

Trace elements such as iron (Fe), cobalt $(\mathrm{Co})$, nickel $(\mathrm{Ni})$, copper $(\mathrm{Cu})$, zinc $(\mathrm{Zn})$, selenium $(\mathrm{Se})$, tungsten $(\mathrm{W})$, and molybdenum (Mo), are essential for the growth and propagation of microorganisms, and are the main constituents of the enzymatic systems of several methanogens such as Methanosarcina barkeri, Methanospirillum hungatii, Methanocorpusculum parvum, Methanobacterium thermoautotrophicum, Methanococcus voltae, Methanococcus vanielli, and Methanococcoides methylutens (Demirel \& Scherer, 2011).

However, some heavy metals such as cooper $(\mathrm{Cu})$, Nickel $(\mathrm{Ni})$, Zinc $(\mathrm{Zn})$, cadmium $(\mathrm{Cd})$, chromium $(\mathrm{Cr})$ and lead $(\mathrm{Pb})$ are reported to be inhibitors, while Fe may exhibit a stimulating effect in the process according to its concentration under certain conditions in biochemical reactions. The inhibition of the process depends on factors such as concentration of metals, in soluble and ionic form, the type of metal, and the quantity and distribution of biomass in the digester or chain of biochemical reactions present in the AD process. The effect of the reported metals is attributable to the disruption of enzyme function and structure by bonding metal ions with the thiol group, and other groups in protein molecules, as well as by replacing natural metals in enzymatic prosthetic groups (Mudhoo \& Kumar, 2013). The need for $\mathrm{Ni}$ in anaerobic digesters containing excreta as a substrate has been reported in literature because it is a component of $\mathrm{F}_{430}$ Factor (coenzyme found in all methanogens, involved in the transfer of electrons and various enzymes). It plays an important role in the structural stability of methanogenic organisms (Speece, 1983; Demirel \& Scherer, 2011; Garuti et al., 2018). 
Additions of Ni, Co, Mo and Se, together with Fe and $\mathrm{Zn}$ have been studied by some authors who report that $\mathrm{Fe}, \mathrm{Cu}$, $\mathrm{Ni}$ and $\mathrm{Zn}$ levels must be increased for high $\mathrm{CH}_{4}$ fermentation productivity (Zhang et al., 2003). The optimal concentrations of Fe and Ni were 1-5 and 0.1 $\mu \mathrm{M}$ respectively for improved growth performance of Methanothrix concilii, which is a mesophilic and methanogenic acetoclastic archaea. The optimal concentrations varied from 250 to $500 \mu \mathrm{M}$ for calcium and magnesium, while concentrations of manganese (Mn), Co, and $\mathrm{Zn}$ together were 2.5, 10, and $5 \mu \mathrm{M}$ respectively (Patel et al., 1988).

According to some authors, Fe is an important trace element and must be supplied during the AD process (Demirel \& Scherer, 2011). Some studies have reported that adding $\mathrm{FeCl}_{2}(4.4 \mathrm{mM})$ in the $\mathrm{AD}$ process of pig waste resulted in sulfide inhibition (Hansen et al., 1999). Recently, some studies have focused on integrating Zero Valiant Iron (ZVI), used to treat pollution, including chlorinated aliphatic compounds, nitrobenzenes, and organic dyes (Shirin and Balakrishnan, 2011; Zhang et al., 2006).

As stated by some authors, ZVI acts as an electron donor for methanogens in integrated anaerobic systems, denitrifying bacteria and decolorizing bacteria (Karri et al., 2005; Wang and Tseng, 2009). The bioavailability is linked to corrosion-induced $\mathrm{H}_{2}$ used to reduce $\mathrm{CO}_{2}$ to $\mathrm{CH}_{4}$ by hydrogenotrophic methanogens like Methanococcus thermolithotrophicus, Methanobacterium thermoautotrophicum, and Methanospirillium hungatei (Belay and Daniels, 1990). The ZVI corrosion process can create a more stable and favorable environment for the growth of anaerobic microorganisms, decreasing the potential for oxidation-reduction (POR) and buffering acid (Li et al., 2013). Sensitive redox compounds can be directly reduced on the iron surface, and organic matter can be removed by the flocculation, adsorption and precipitation processes for colloids of $\mathrm{Fe}(\mathrm{OH})_{2}$ and $\mathrm{Fe}(\mathrm{OH})_{3}$ (Noubactep, 2008).

The use of ZVI powder in anaerobic treatment systems for pig wastewater revealed that there was an increase of $145.5 \%$ in the associated $\mathrm{CH}_{4}$ yield with a COT / VS removal ratio of $56.2 \%$ for a dosage of $25 \mathrm{~g} / \mathrm{L} \mathrm{Fe}$ at a temperature of $30{ }^{\circ} \mathrm{C}(\mathrm{Wu}$ et al., 2015). Another study indicated that the application of $20 \mathrm{~g} / \mathrm{L}$ in the form of microscale zero-valent iron (mZVI) for a temperature of $35^{\circ} \mathrm{C}$ increased $20 \%$ to $26 \%$ of $\mathrm{CH}_{4}$ yield, indicating the positive role of Fe in the AD process (Liang et al., 2017). Feng et al. (2014) observed that the addition of ZVI increased protein degradation by $21.9 \%$, and the activities of several key enzymes in hydrolysis and acidification increased 0.6-1 times, in addition to the increase in $\mathrm{CH}_{4}$ production by $43.5 \%$ and sludge by $12.2 \%$.

Some studies have discussed the effects of antibiotics in excrement on AD processes, discussing the improvement of hydrogenotrophic activities by adding ZVI. Yin et al. (2018) reported that the use of chlortetracycline (CTC) and oxytetracycline (OTC) negatively affected the bacterial community in the methanogenic and acidogenic stages, respectively, in addition to negatively influencing the archaea species in the methanogenic stage, resulting in low energy conversion efficiency. Sulfonamides are the most used type of antibiotics in the pig industry, especially sulfadiazine (SDZ), with concentrations in the order of 91-235 mg / L found in pig manure according to Yang et al. (2019). In one study carried out by Huang et al. (2019), 5.0 $\mathrm{g} / \mathrm{L}$ of ZVI significantly optimized the acidification process, enriching the bacteria Clostridia and Bacteroidia, which are mainly responsible for producing VFA and $\mathrm{H}_{2}$, providing greater substrate availability for methanogenesis.

\section{Application of AD Systems: Perspectives for Global Advances, Potential Application in Pig Farming, Opportunities for Mitigating GHGs, and Bottlenecks}

Biogas can be converted into electricity and heat in cogeneration units (combined heat and power systems - CHP) after undergoing a simple desulfurization and drying process. It can be burned for heat production or replace carbon compounds in plastic products. Biomethane can be formed after a purification process, which can be stored and used in all commonly known 
applications for natural gas, according to the legislative restrictions or permits for each location. It can be used as a flex fuel in engines, and is very important in the sustainable context of the energy supply (Costa Gomez, 2013 and Brasil, 2015).

Biogas technology had the third highest growth rate (12.3\%), followed by solar thermal energy (11.5\%), and liquid biofuels (10\%) from 1990 to 2016. Nonetheless, a small contribution to renewable sources for the total energy supply is reported. This sector, comprised of wind, solar, tidal energy, biogas, liquid biofuels, and renewable urban waste, still constitutes only $7.9 \%$ of the total energy supply. The total share of renewable energy in countries in the Organization for Economic or Economic Cooperation and Development (OECD) increased from 3.1\% in 1990 to 35.5\% in 2017. Biogas technology increased from 0.3\% to $3 \%$, an energy growth from 3.7 TWh to 81.2 TWh (IEA, 2018). Furthermore, the European target expects anaerobic digestion to expand to $20 \%$. However, this advance will depend on exceeding the $20 \%$ mark for energy derived from renewable sources. This expansion will depend on overcoming restrictions that require registering using the digestate as a fertilizer (Loyon, 2016).

The OECD countries were responsible for producing 79.6\% of all biogas in 2017. Germany has a large share, where electricity production has grown at an average rate of $20 \%$ per year since 1990, totaling a production of 34.3 TWh in 2017 and representing $42.2 \%$ of the OECD's total electricity generation from biogas. As the group's second largest producer, the USA produced $12.5 \mathrm{TWh}$, or $15.4 \%$ of its electricity from biogas. Despite its large share of production, the average annual growth rate in the United States (6.2\% since 1990) has been much slower than in the EU countries using this technology, such as Belgium and Italy, which have growth rates of $20.0 \%$ and $36.1 \%$, respectively. The latter is the third largest producer in the OECD, having produced 8.3 TWh (10.2\% of production), followed by the United Kingdom, which produced 7.7 TWh (9.5\% of production) in 2017 (IEA, 2018).

A low application of this technology in Brazil is still reported with only 39 biogas plants, which produce approximately 196.32 MW, constituting about $1.28 \%$ of the power generation of thermoelectric plants (TPs) (ANEEL, 2020). Furthermore, only $0.01 \%$ of energy produced from animal waste in the country (Castro e Silva et al., 2021). Such fact occurs due to the minimum tariff paid for operating conventional TPs (86.9 USD / MWh), about 18\% lower when compared to biogas plants (105.3 USD / MWh) (Rangel et al., 2011). Mapping conducted by Santos et al. (2018) reveals great energy potential in the country, and maximum biogas production can reach 1124,814 x $106 \mathrm{Nm}^{3}$ / year, accounting for approximately $250.71 \mathrm{MW}$ and $1.76 \mathrm{TWh} /$ year, with emission reductions in the order of $0.713 \mathrm{MtCO}_{2} /$ year.

Nowadays, implementing biomass digestion plants is even more feasible now due to increased levels of excrement produced worldwide, since there is a high waste flow resulting from the production models. Recent research estimates the planet will be generating approximately 5 billion tons of waste per year, with the vast majority coming from cattle by 2030 . In the Netherlands, about $80 \%$ of farms have already produced more cow manure than they can legally use as fertilizer, whereas China, the world's largest pig producer, has resorted to drastic measures to try to reduce the amount of manure discharged into rivers. . Between 2010 and 2016, about 424 serious pollution accidents related to waste disposal were recorded in the United Kingdom involving dairy cattle, poultry, and pig farms (Cox, 2019).

Harmful gases such as $\mathrm{NH}_{3}, \mathrm{~N}_{2} \mathrm{O}$, and $\mathrm{H}_{2} \mathrm{~S}$ in large amounts can be lethal to populations, resulting in higher susceptibility to developing diseases such as chronic asthma, respiratory irritation, immune suppression, and mood disorders. Agricultural waste is among the largest sources of $\mathrm{CH}_{4}$ emissions in Europe, and is one of the main reasons for GHGs emissions, which have almost doubled from 1980 to 2010 (Cox, 2019). Bsides, the pig farming industry emits approximately 668 million tons of $\mathrm{CO}_{2} \mathrm{eq}$, and industrial systems are responsible for the majority of production and emissions. The AD systems can address the storage, processing, and post-processing stages of manure. The first two phases have higher emission intensities, around $27.4 \%$, totaling $19.2 \%$ in the form of $\mathrm{CH}_{4}$ and $8.2 \%$ in the form of $\mathrm{N}_{2} \mathrm{O}$, and come from predominantly anaerobic storage systems in hot climates. The AD systems can reduce GHGs emissions by $5.7 \%$, in the post-processing and transportation phases of manure (FAO, 2013). 
Although these results are positive, the $\mathrm{AD}$ processes have limitations which are closely linked to problems such as the diversity of substrates (different levels of lipids, proteins and polysaccharides), $\mathrm{NH}_{3}$ inhibition, microbial flora washing, and high variability and low CH4 yield (Arif et al., 2018). These last two factors make AD installations less attractive in financial terms in Brazil.

Some studies on adding trace elements presented in literature show higher $\mathrm{CH}_{4}$ yields associated with expressive reductions in VFA and reduced organic loads in AD treatment methods. However, further in-depth studies regarding life cycle and economic feasibility analysis should be carried out, that include variables like Net Present Value (NPV), Internal Rate of Return (IRR), and the Levelized Cost of Energy (LCOE). Detailed assessments of the impacts of using these additives can be carried out in each of the stages of the process for implementing treatment plants. The resulting revenues and costs from optimizing energy efficiency could be further studied.

\section{Final Considerations}

The development of agro-industrial systems led to the modernization of production models, resulting pig farming an important economic activity for the Brazilian and international markets. Despite specialization and optimization in production systems, the integrated production method has resulted in increased waste flows that are still being incorrectly disposed by the main pig-producing countries. Such fact is a serious socio-environmental problem, since manure can be discarded into rivers and also emitting greenhouse gas emissions. The Anaerobic digestion (AD) systems can address the storage, processing, and postprocessing stages for manure, reducing GHGs levels emissions. Although AD systems can be beneficial, they are limited by the nature of the substrate used, and high variability in $\mathrm{CH}_{4}$ production, resulting in low economic viability in Brazil.

Mineral additives can increase the profitability of such systems, by increasing methane yields with expressive reductions in VFA and reduced organic loads in such treatment. According to this research, Chinas has developed extensive studies about the use of trace elements in mineral forms to optimize the AD process, however, more in-depth studies should be carried out on life cycle analysis and economic viability. Some suggestions for future works include the analysis of the impact of mineral additives in the anaerobic digestion of other types of feedstock, such as cattle and poultry manure. Furthermore, a detailed assessment of the impacts of using these additives at each stage of the process could be applied to determine the revenues and costs by optimizing energy efficiency.

\section{Competing interests}

We have no conflict of interest to declare. The authors declare that they have no known competing financial interests or personal relationships that could have appeared to influence the work reported in this paper.

\section{References}

ABCS (2016). Mapping of Brazilian pig farming. Brazilian Association of Pig Breeders. Brasília (Brazil). Brazilian Association of Pig Breeders (ABCS)

ABCS. (2018). Market: Pig farming starts 2018 with timid results and moment calls for caution. http://www.abcs.org.br/informativo-abcs/2537-mercadosuinocultura-inicia-2018-com-resultados-timidos-e-momento-pede-cautela. Brazilian Swine Breeders Association (ABCS).

ABIPECS. (2011). Brazilian Pork Producing and Exporting Industry Association, $2011 . \quad$ Report $2011 . \quad$ http://abpabr.com.br/setores/suinocultura/publicacoes/relatorios-anuais. Brazilian Pork Producing and Exporting Industry Association (ABIPECS).

ABPA. (2016). Brazilian Animal Protein Association. 2016 Anual Report. http://abpa-br.com.br/setores/suinocultura/publicacoes/relatorios-anuais. Brazilian Animal Protein Association (ABPA).

ABPA. (2018). Brazilian Animal Protein Association. 2018 Annual Report. http://abpa-br.com.br/setores/suinocultura/publicacoes/relatorios-anuais. Brazilian Animal Protein Association (ABPA). 
AGROCERES PIC (2019). A Empresa (Business Company, “In Portuguese”). https://agroceres.com.br/empresa.aspx. AGROCERES.

Andriani, D., Wresta, A., Atmaja, T. D., \& Saepudin, A. (2014). A Review on Optimization Production and Upgrading Biogas Through CO 2 Removal Using Various Techniques. Applied Biochemistry and Biotechnology, 172 (4), 1909-1928. https://doi.org/10.1007/s12010-013-0652-x.

ANEEL. (2020). Brazilian National Electric Energy Agency. BIG: Generation information bank. https://www2.aneel.gov.br/aplicacoes/capacidadebrasil/capacidadebrasil.cfm. Brazilian National Electric Agency (ANEEL).

ANEEL. (2012). Brazilian National Electric Energy Agency. Normative Resolution No. 482 2012. http://www2.aneel.gov.br/cedoc/bren2012482.pdf. Brazilian National Electric Energy Agency (ANEEL).

ANEEL. (2015). Brazilian National Electric Energy Agency. Normative Resolution No. 687 2015. http://www2.aneel.gov.br/cedoc/ren2015687.pdf. Brazilian National Electric Energy Agency (ANEEL).

ANP. (2015). Brazilian National Agency of Petroleum, Natural Gas and Biofuels. Resolution No. 8 2015. https://www.legisweb.com.br/legislacao/?id=280722. Brazilian National Agency of Petroleum, Natural Gas and Biofuels (ANP).

ANP. (2017). Brazilian National Agency of Petroleum, Natural Gas and Biofuels. Resolution No. 685 2017. https://www.legisweb.com.br/legislacao/?id=345545. Brazilian National Agency of Petroleum, Natural Gas and Biofuels (ANP).

Aponte-Morales, V. E., Tong, S., \& Ergas, S. J. (2016). Nitrogen Removal from Anaerobically Digested Swine Waste Centrate Using a Laboratory-Scale Chabazite-Sequencing Batch Reactor. Environmental Engineering Science, 33(5), 324-332. https://doi.org/10.1089/ees.2015.0577.

Araújo, M. J. (2005). Agribusiness Fundamentals, São Paulo ("In Portuguese”).

Arif, S., Liaquat, R., \& Adil, M. (2018). Applications of materials as additives in anaerobic digestion technology. Renewable and Sustainable Energy Reviews, 97, 354-366. https://doi.org/10.1016/j.rser.2018.08.039.

Barros, R. M. (2012). Treaty on solid waste: management, use and sustainability. https://elibro.net/ereader/elibrodemo/175169.

Barton, L. L. (Ed.). (1995). Sulfate-Reducing Bacteria. Springer US. http://link.springer.com/10.1007/978-1-4899-1582-5.

Belay, N., \& Daniels, L. (1990). Elemental metals as electron sources for biological methane formation from $\mathrm{CO}_{2}$. Antonie van Leeuwenhoek, 57(1), 1-7. https://doi.org/10.1007/bf00400329.

Brasil. (2015). Brazil-Germany Project to Promote the Energy Use of Biogas in Brazil (Probiogás) Preliminary project for a biogas research and training plant. Brazil-Germany Project to Promote the Energy Use of Biogas in Brazil (Probiogás), 1 st edition, Ministry of cities, Brasília ("In Portuguese”).

Brazil. (2010a). Decree No. 7,404. https://www.planalto.gov.br/ccivil_03/_ato2007-2010/2010/decreto/d7404.htm. Off Fed Gazette, Brasília. (“In Portuguese").

Brazil. (2010b). Ministry of the Environment. Law No. 12,305. http://www.planalto.gov.br/ccivil_03/_Ato2007-2010/2010/Lei/L12305.htm. Off Fed Gazette, Brasília. ("In Portuguese").

Brazil (2006). National Environmental Council. Resolution No. 375 2006. http://www2.mma.gov.br/port/conama/res/res06/res37506.pdf. National Environmental Council, Brasília ("In Portuguese”).

Brazil (2011). National Environmental Council. Resolution No. 430 2011. http://www2.mma.gov.br/port/conama/legiabre.cfm?codlegi=646. National Environmental Council, Brasília ("In Portuguese”).

Burton, C. H. (Ed.). (2003). Manure management: Treatment strategies for sustainable agriculture, $2^{\text {nd }}$ edition, Silsoe Research Institute., Bedford.

Castro e Silva, H. L. (2019). Technical and Economic Feasibility Analysis of the Anaerobic Biodigestion Process in the Treatment of Pig Waste from an Agroindustry in the Municipality of Cachoeira de Minas (MG) in a Batch Type Reactor. Master's Dissertation. The Federal University of Itajubá, Itajubá, 2019 (In Portuguese).

Castro e Silva, H. L., Córdova, M. E. H., Barros, R. M., Tiago filho, G. L., Lora, E. E. S, Santos, A. H. M., Santos, L. F. S., Botan, M. C. C., Pedreira, J.R., \& Flauzino, B. K. (2020). Technical and economic feasibility of lab-scale biogas production experiments from swine manure in Southern Minas Gerais, Brazil. Biomass and Bioenergy. (Resubmitted in June 2020).

Castro e Silva, H. L., Silva, A. M. L., Barros, R. M., Santos, I. F. S., \& Rocha, J. V (2021). Addition of iron ore tailings to increase the efficiency of anaerobic digestion of pig manure: A technical and economic analysis. Biomass and Bioenergy, 148, 106013. https://doi.org/10.1016/j.biombioe.2021.106013

Chai, S., Guo, J., Chai, Y., Cai, J., \& Zhang, Q. (2013). The effect of trace element addition on the performance efficiency of an Anaerobic Moving Bed Biofilm Reactor treating wine vinasse. Journal of Pure and Applied Microbiology. 7, 753-758.

Chou, H.-H., Huang, J.-S., Chen, W.-G., \& Ohara, R. (2008). Competitive reaction kinetics of sulfate-reducing bacteria and methanogenic bacteria in anaerobic filters. Bioresource Technology, 99(17), 8061-8067. https://doi.org/10.1016/j.biortech.2008.03.044. 
Costa Filho, D. V., Silva, A. J., Silva, P. A. P., \& Sousa, F. C. (2017). Use of agro-industrial residues in the production of by-products. in: International Congress of Agricultural Sciences. Rio Grande do Norte (Brazil), pp. 1-8. ("In Portuguese").

Costa Gomez, C. (2013). Biogas as an energy option: an overview. in: Wellinger, A., Murphy, J., Baxter, D. (Eds.), The Biogas Handbook: Science, Production and Applications. Woodhead Publishing, Sawston, pp. 1-16.

Costa, A. A., Silva, M. O., Paron, M. E., Carvalho, J. F. C., Júnior, J. L., Sagula, A. J., Fernandes, A., Cangani, M. T., Azevedo, S. S., \& Soto, F. R. M. (2017). Biogas production potential in anaerobic digestion of swine manure with different solid fraction concentrations and temperatures. Journal of Environmental Studies. 19, 6-17. http://dx.doi.org/10.7867/1983-1501.2017v19n1p6-17.

Cruz Viggi, C., Rossetti, S., Fazi, S., Paiano, P., Majone, M., \& Aulenta, F. (2014). Magnetite Particles Triggering a Faster and More Robust Syntrophic Pathway of Methanogenic Propionate Degradation. Environmental Science \& Technology, 48(13), 7536-7543. http://dx.doi.org/10.1021/es5016789.

Cruz, H. M. da, Barros, R. M., Santos, I. F. S. dos, \& Tiago Filho, G. L. (2019). Estudo do potencial de geração de energia elétrica a partir do biogás de digestão anaeróbia de resíduos alimentares. Research, Society and Development, 8(5), e3785811. https://doi.org/10.33448/rsd-v8i5.811.

Curnow, M. (2021). Managing manure to reduce greenhouse gas emissions. South Perth. https://www.agric.wa.gov.au/climate-change/managing-manurereduce-greenhouse-gas-emissions.

Demirel, B., \& Scherer, P. (2011). Trace element requirements of agricultural biogas digesters during biological conversion of renewable biomass to methane. Biomass and Bioenergy, 35(3), 992-998. https://doi.org/10.1016/j.biombioe.2010.12.022.

Deublein, D., \& Steinhauser, A. (2008). Biogas from Waste and Renewable Resources. Wiley-VCH Verlag GmbH \& Co. KGaA. http://doi.wiley.com/10.1002/9783527621705.

Diesel, R., Miranda, C. R., \& Perdomo, C. C. (2002). Collection of Pig Waste Technologies. Technical Assistance and Rural Extension Enterprise. Porto Alegre. Technical Assistance and Rural Extension Enterprise (EMATER). ("In Portuguese”).

EC - European Community. (2000). Directive 2000/60 / EC of the European Parliament and of the Council of 23 October 2000 establishing a framework for Community action in the field of water policy. http://eur-lex.europa.eu. Official Journal of the European Communities.

EC - European Community. (2001). Directive 2001/81 / EC of the European Parliament and of the Council of 23 October 2001 on national emission limit values for certain air pollutants. http://eur-lex.europa.eu. Official Journal of the European Communities.

EC - European Community. (2009). Directive 2009/28 / EC of the European Parliament and of the Council, of 23 April 2009, on the promotion of the use of energy from renewable sources. http://eur-lex.europa.eu. Official Journal of the European Union.

EC - European Community. (2020). Financing a sustainable european economy - taxonomy report: technical annex. https://ec.europa.eu/info/sites/default/files/business_economy_euro/banking_and_finance/documents/200309-sustainable-finance-teg-final-report-taxonomyannexes_en.pdf

EEC - European Economic Community. (1991). Council Directive 91/676 / EEC of 12 December 1991 on the protection of waters against pollution caused by nitrates from agricultural sources. http://eur-lex.europa.eu. Official Journal of the European Communities.

EPA - Environmental Protection Agency. (2014). Biogas opportunities roadmap - Voluntary actions to reduce methane emissions and increase energy independence. https://www.epa.gov/sites/default/files/2015-12/documents/biogas-roadmap.pdf.

EPA - Environmental Protection Agency. (2017). Understanding global warming potentials. https://www.epa.gov/ghgemissions/understanding-global-warmingpotentials. Environmental Protection Agency (EPA).

EUROSTAT - European Statistical Office. (2019). Number of pigs. https://ec.europa.eu/eurostat/databrowser/view/tag00018/default/table?lang=en. European Statistical Office (EUROSTAT).

EUROSTAT - European Statistical Office. (2019). Agriculture in the European Union and the Member States - Statistical factsheets, 2013. http://ec.europa.eu/agriculture/statistics/factsheets/index_en.htm. European Statistical Office (EUROSTAT).

FAO - Food and Agricultural Organization of the United Nations. (2013). Greenhouse gas emissions from ruminant supply chains - A global life cycle assessment.

FAO - Food and Agricultural Organization of the United Nations. (2014a). Sources of meat http://www.fao.org/ag/againfo/themes/en/meat/backgr_sources.html. Food and Agricultural Organization of the United Nations (FAO).

FAO - Food and Agricultural Organization of the United Nations. (2014b). Russian Federation - Meet sector review. http://www.fao.org/3/a-i3533e.pdf. Food and Agricultural Organization of the United Nations (FAO).

FAO - Food and Agricultural Organization of the United Nations. (2019). Livestock primary. http://www.fao.org/faostat/en/\#data/QL/visualize. Food and Agricultural Organization of the United Nations (FAO). 
Feng, Y., Zhang, Y., Quan, X., \& Chen, S. (2014). Enhanced anaerobic digestion of waste activated sludge digestion by the addition of zero valent iron. Water Research, 52, 242-250. https://doi.org/10.1016/j.watres.2013.10.072.

Ferreira, R. de S. (2020). Biodigesters and the factors that determine their maximum production. Research, Society and Development, 9 (7), e544972677. https://doi.org/10.33448/rsd-v9i7.2677.

Foged, H. L., Flotats, X., Bonmati, A., Palatsi, B. J., Magri, A., \& Schelde, K. M. (2011). Inventory of Manure Processing Activities in Europe. Technical Report No. I concerning "Manure Processing Activities in Europe" to the European Commission, Directorate-General Environment.

Fortune, A. (2019). Canadian pork industry given \$6m to grow exports. https://www.globalmeatnews.com/Article/2019/07/28/Canadian-pork-industry-given$6 \mathrm{~m}$-to-grow-exports.

Gaete, A. V., Teodoro, C. E. de S., \& Martinazzo, A. P. (2020). Use of agro-industrial waste for cellulase production: a review. Research, Society and Development, 9 (8). https://doi.org/10.33448/rsd-v9i8.5785.

Garuti, M., Langone, M., Fabbri, C., \& Piccinini, S. (2018). Methodological approach for trace elements supplementation in anaerobic digestion: Experience from full-scale agricultural biogas plants. Journal of Environmental Management, 223, 348-357. https://doi.org/10.1016/j.jenvman.2018.06.015.

Godrat, A. G., Tabatabaei, M., Aghbashlo, M., \& Mussato, S. I. (2019). Waste management strategies, the state of the art. in: Tabatabaei, M., Ghanavati, H. (Org.), Biogas: Fundamentals, Process, and Operation. Springer International Publishing, New York, pp. 1-34.

GOVERNMENT OF CANADA. (2019). Government of Canada helps strengthen the Canadian Pork Industry. https://www.canada.ca/en/agriculture-agrifood/news/2019/04/government-of-canada-helps-strengthen-the-canadian-pork-industry.html. GOVERNMENT OF CANADA.

Grey, S. (2019). Pig production in Russia. https://www.pig333.com/articles/pig-production-in-russia_2044/.

Guimarães, D., Amaral, G., Maia, G., Lemos, M., Ito, M., \& Custodio, S. (2017). Pig farming: Structure of the production chain, panorama of the productive sector and in the world and the support of BNDS. Sectorial BNDES, 1, 85-136 ("In Portuguese").

Hansen, K. H., Angelidaki, I., \& Ahring, B. K. (1999). Improving thermophilic anaerobic digestion of swine manure. Water Research, 33(8), 1805-1810. https://doi.org/10.1016/S0043-1354(98)00410-2.

Huang, W., Yang, F., Huang, W., Lei, Z., \& Zhang, Z. (2019). Enhancing hydrogenotrophic activities by zero-valent iron addition as an effective method to improve sulfadiazine removal during anaerobic digestion of swine manure. Bioresource Technology, 294, 122178. https://doi.org/10.1016/j.biortech.2019.122178.

IEA - INTERNATIONAL ENERGY AGENCY. (2018). Renewables information: Overview. https://www.iea.org/reports/world-energy-outlook2018/renewables.

Jinadasa, W., Wakjera, E. J., \& Bakke, R. (2010). Full scale process design for energy recovery from wine manure. in: Linnaeus eco-tech, Kalmar, pp. $592-597$. https://open.lnu.se/index.php/eco-tech/article/view/664.

Jørgensen, P. J. (2009). Biogas - Green Energy, second edition, Aarhus University, Denmark.

Kelessidis, A., \& Stasinakis, A. S. (2012). Comparative study of the methods used for treatment and final disposal of sewage sludge in European countries. Waste Management, 32(6), 1186-1195. https://doi.org/10.1016/j.wasman.2012.01.012.

Kleerebezem, R., Joosse, B., Rozendal, R., \& Van Loosdrecht, M. C. M. (2015). Anaerobic digestion without biogas? Reviews in Environmental Science and Bio/Technology, 14(4), 787-801. https://doi.org/10.1007/s11157-015-9374-6.

Kunz, A., Higarashi, M. M., \& Oliveira, P. A. (2005). Swine manure management and treatment technologies studied in Brazil. Science \& Technology Notebooks, $22,651-665$.

Kunz, A., Steinmetz, R. L. R., \& Amaral, A. C. (2019). Fundamentals of anaerobic digestion, biogas purification, use and treatment of the digestate, Embrapa Suínos e Aves, Concórdia ("In Portuguese").

Li, W.-W., Zhang, Y., Zhao, J.-B., Yang, Y.-L., Zeng, R. J., Liu, H.-Q., \& Feng, Y.-J. (2013). Synergetic decolorization of reactive blue 13 by zero-valent iron and anaerobic sludge. Bioresource Technology, 149, 38-43. https://doi.org/10.1016/j.biortech.2013.09.041.

Liang, Y., Li, X., Zhang, J., Zhang, L., \& Cheng, B. (2017). Effect of microscale ZVI/magnetite on methane production and bioavailability of heavy metals during anaerobic digestion of diluted pig manure. Environmental Science and Pollution Research, 24(13), 12328-12337. https://doi.org/10.1007/s11356-017$8832-9$.

Liu, L., Zhang, T., Wan, H., Chen, Y., Wang, X., Yang, G., \& Ren, G. (2015). Anaerobic co-digestion of animal manure and wheat straw for optimized biogas production by the addition of magnetite and zeolite. Energy Conversion and Management, 97, 132-139. https://doi.org/10.1016/j.enconman.2015.03.049.

Loyon, L. (2017). Overview of manure treatment in France. Waste Management, 61, 516-520. https://doi.org/10.1016/j.wasman.2016.11.040.

Maldaner, L., Wagner-Riddle, C., VanderZaag, A. C., Gordon, R., \& Duke, C. (2018). Methane emissions from storage of digestate at a dairy manure biogas facility. Agricultural and Forest Meteorology, 258, 96-107. https://doi.org/10.1016/j.agrformet.2017.12.184. 
Martínez, Y., \& Albiac, J. (2006). Nitrate pollution control under soil heterogeneity. Land Use Policy, 23(4), 521-532. https://doi.org/10.1016/j.landusepol.2005.05.002.

Matulaitis, R., Juškienė, V., \& Juška, R. (2015). Measurement of methane production from pig and cattle manure in Lithuania. Zemdirbyste-Agriculture, 102(1), 103-110. https://doi.org/10.13080/z-a.2015.102.013.

Molinuevo, B., Garcia, M. C., Léon, M. C., \& Acítores, M. (2008). Anaerobic co-digestion of animal wastes (poultry litter and pig manure) with vegetable processing wastes. In: International Ramiran Conference, Albena, pp. 110-114.

Moraes, V. G., \& Capanema, L. (2012). The genetics of swine chickens: the strategic importance of their development for Brazil. Sectorial BNDES, 1, 119-154. ("In Portuguese").

Mudhoo, A., \& Kumar, S. (2013). Effects of heavy metals as stress factors on anaerobic digestion processes and biogas production from biomass. International Journal of Environmental Science and Technology, 10(6), 1383-1398. https://doi.org/10.1007/s13762-012-0167-y.

Noubactep, C. (2008). A critical review on the process of contaminant removal in $\mathrm{Fe}^{0}-\mathrm{H}_{2} \mathrm{O}$ systems. Environmental Technology, 29(8), 909-920. https://doi.org/10.1080/09593330802131602.

NPPC - NATIONAL PORK PRODUCERS COUNCIL. (2019). Pork facts. http://nppc.org/pork-facts/. 2019. National Pork Producers Council (NPPC).

OIE - World Organization for Animal Health. (2019). Resolution No. 15. Recognition of the foot and mouth disease status of members. https://www.oie.int/fileadmin/Home/eng/Animal_Health_in_the_World/docs/pdf/Resolutions/2019/A_R15_FMD_status.pdf. World Organization For Animal Health.

Pagliuso, J. D., Regattieri, \& C. R. (2008). Study of the use of biogas energy from slurry incineration for electricity generation. Brazilian Journal of Environmental Sciences, 1, 32-38 ("In Portuguese”).

Parawira, W. (2012). Enzyme research and applications in biotechnological intensification of biogas production. Critical Reviews in Biotechnology, 32(2), 172186. http://dx.doi.org/10.3109/07388551.2011.595384.

Patel, G. B., Baudet, C., \& Agnew, B. J. (1988). Nutritional requirements for growth of Methanothrix concilii. Canadian Journal of Microbiology. $34,73-77$.

Perdomo, C. C., Oliveira, P. A. V., \& Kunz, A. (2003). Swine manure treatment systems: Technological inventory, Concórdia. (“In Portuguese”).

Pereira, E. R., Demarchi, J. J. A. A., Budiño, F. E. L. (2009). Biodigesters: Technology for livestock wastewater management. http://www.iz.sp.gov.br/pdfs/1255981651.pdf.

PIG PROGRESS. (2016). Significant decrease in sow numbers in Europe. http://www.pigprogress.net/Sows/Arti-cles/2016/4/Significant-decrease-of-sownumbers-in-Europe-2794518W/.

PPC - Professional Pig Community. (2016). Russian 20 largest pork producers. https://www.pig333.com/company_news/russian-20-largest-porkproducers_11880/. Professional Pig Community (PPC).

PPC - Professional Pig Community. (2019a). Pig production figures in Russia in 2018. https://www.pig333.com/latest_swine_news/pig-production-figures-inrussia-in-2018_14605/. Professional Pig Community (PPC).

PPC - Professional Pig Community. (2019b). Russian pig profitability drops. https://www.globalmeatnews.com/Article/2019/06/24/Russian-pig-profitabilitydrops. Professional Pig Community (PPC).

Rangel, M. S., Borges, P. B., \& Santos, L.F.S. (2011). Comparative analysis of renewable energy costs and tariffs in Brazil. Brazilian Journal of Renewable Energies, 5, 267-277 ("In Portuguese").

Ribeiro, E. M., Mambeli Barros, R., Tiago Filho, G. L., dos Santos, I. F. S., Sampaio, L. C., dos Santos, T. V., da Silva, F. dGB, Silva, A. P. M., \& de Freitas, J. V. R. (2018). Feasibility of biogas and energy generation from poultry manure in Brazil. Waste Management \& Research, 36(3), $221-235$. https://doi.org/10.1177/0734242X17751846.

Ribeiro, S. A. dos S., Junho, A. L., Barros, R. M., Santos, I. F. S. dos, Filho, G. L. T., Martuscelli, E., \& Freitas, J. V. R. de. (2020). Preliminary study of biodigestion of bovine manure with whey in the double-stage digestion system with biogas purification. Research, Society and Development, $9(8)$, e646985911. https://doi.org/10.33448/rsd-v9i8.5911.

Ritchie, H. (2019). Carne na alimentação: Quais países lideram o ranking. https://www.bbc.com/portuguese/geral-47125834.

Santini, G. A., \& Souza Filho, H. M. (2004). Technological changes in agro-industrial chains: An analysis of the processing links of beef cattle, beef poultry and pig farming. In: Congress of the Brazilian Society of Rural Economy, Cuiabá, pp. 1-12. ("In Portuguese”).

Santos, A. R. (2011). Traceability "from the laboratory to the table" - A study of the pork meat production chain in the company doux. Master's dissertation in Administration. University of Caxias do Sul, Caxias do Sul ("In Portuguese"). 
Santos, I. F. S., Braz Vieira, N. D., de Nóbrega, L. G. B., Barros, R. M., \& Tiago Filho, G. L. (2018). Assessment of potential biogas production from multiple organic wastes in Brazil: Impact on energy generation, use, and emissions abatement. Resources, Conservation and Recycling, 131, 54-63. https://doi.org/10.1016/j.resconrec.2017.12.012.

SARGA - Aragonese Society of Agro-Environmental Management. (2015). Evaluation of manure systems in Europe. https://core.ac.uk/download/pdf/46606176.pdf. Aragonese Society of Agro-Environmental Management, Spain.

Shirin, S., \& Balakrishnan, V. K. (2011). Using Chemical Reactivity To Provide Insights into Environmental Transformations of Priority Organic Substances: The Fe ${ }^{0}$-Mediated Reduction of Acid Blue 129. Environmental Science \& Technology, 45(24), 10369-10377. https://doi.org//10.1021/es202780r.

Smith, S., \& Braathen, N. A. (2015). Monetary carbon values in policy appraisal: An overview of current practice and key issues. OECD Environment Working Papers, No 92, Organization for Economic Cooperation and Development.

Song, X., Zhang, Q., Han, B.; Liang, J., Zhai, Z., \& Du, L. (2016). Anaerobic co-digestion of pig manure with dried maize straw. BioResources. 11, 8914-8928.

Souza, J. C. P. V. B., Amaral, A. L., Morés, N., Treméa, S. L., Miele, M., \& Santos Filho, J. I. (2013). Piglet production systems based on planning, management and operational standards. Concórdia. ("In Portuguese").

Speece, R. E. (1983). Anaerobic biotechnology for industrial wastewater treatment. Environmental Science \& Technology, 17(9), 416A-427A. http://dx.doi.org/10.1021/es00115a001.

Karri, S., Sierra-Alvarez, R., \& Field, J. A. (2005). Zero valent iron as an electron-donor for methanogenesis and sulfate reduction in anaerobic sludge. Biotechnology and Bioengineering, 92(7), 810-819. https://doi.org/10.1002/bit.20623.

STATISTICS CANADA. (2014). The changing face of the Canadian hog industry. https://www150.statcan.gc.ca/n1/pub/96-325-x/2014001/article/14027eng.pdf.

Sutton, M. A., Oenema, O., Erisman, J. W., Leip, A., van Grinsven, H., \& Winiwarter, W. (2011). Too much of a good thing. Nature, 472 (7342), 159-161. https://doi.org/10.1038/472159a.

Tejon, J. L. (2019). Agroindustry is the largest sector of Brazilian industry, says Tejon. 2019. https://rvtv.com.br/2019/01/31/agroindustria-tejon/.

Terhorst, K. I. L. \& Schmitz, J. A. K. (2017). From pig to pig: History of pig farming and eating habits associated with products derived from it among farmers in the Taquar Valley. in: Menasche, R. (Org.), Family farming at the table: Knowledge and practices of food in the Taquari Valley. Federal University of Rio Grande do Sul, Porto Alegre, pp. 100-119.

Tooge, R. (2020). Agribusiness grows $3.8 \%$ and represents 21\% of Brazilian GDP in 2019, says CNA. https://g1.globo.com/economia/agronegocios/noticia/2020/03/09/agronegocio-cresce-38percent-e-representa-21percent-do-pib-brasileiro-em-2019-dizcna.ghtml.

UNECE - The United Nations Economic Commission for Europe. (1999). Protocol to the 1979 convention on long-range transboundary air pollution to abate acidification, eutrophication and ground-level ozone (Gothenburg protocol). https://www.unece.org/env/lrtap/multi_h1.html.

USDA - United States Department of Agriculture. (2016). Livestock and poultry. https://www.fas.usda.gov/data/livestock-and-poultry-world-markets-and-trade. United States Department of Agriculture (USDA).

USDA - United States Department of Agriculture. (2018). Livestock slaughter annual summary. https://www.pork.org/facts/stats/structure-andproductivity/state-rankings-by-hogs-and-pigs-inventory/. United States Department of Agriculture (USDA).

USITC - United States International Trade Commission. (2014). Pork and swine - Industry \& trade summary. https://www.usitc.gov/publications/332/pork_and_swine_summary_its_11.pdf. Office of Industries, United States International Trade Commission (USITC).

Wang, Q., Yang, Y., Li, D., Feng, C., \& Zhang, Z. (2012). Treatment of ammonium-rich swine waste in modified porphyritic andesite fixed-bed anaerobic bioreactor. Bioresource Technology, 111, 70-75. https://doi.org/10.1016/j.biortech.2012.01.182.

Wang, S.-M., \& Tseng, S. (2009). Dechlorination of trichloroethylene by immobilized autotrophic hydrogen-bacteria and zero-valent iron. Journal of Bioscience and Bioengineering, 107(3), 287-292. https://doi.org/10.1016/j.jbiosc.2008.11.010.

Wang, Y., Ren, G., Zhang, T., Zou, S., Mao, C., \& Wang, X. (2017). Effect of magnetite powder on anaerobic co-digestion of pig manure and wheat straw. Waste Management, 66, 46-52. https://doi.org/10.1016/j.wasman.2017.04.031.

Wilkie, A., Goto, M., Bordeaux, F. M., \& Smith, P. H. (1986). Enhancement of anaerobic methanogenesis from napiergrass by addition of micronutrients. Biomass, 11(2), 135-146. https://doi.org/10.1016/0144-4565(86)90043-0.

Wu, D., Zheng, S., Ding, A., Sun, G., \& Yang, M. (2015). Performance of a zero valent iron-based anaerobic system in swine wastewater treatment. Journal of Hazardous Materials, 286, 1-6. https://doi.org/10.1016/j.jhazmat.2014.12.029.

Yang, Y., Huang, W., \& Huang, W. (2019). Antibiotic Inhibition on Anaerobic Digestion of Animal Manure and Controlling Strategies: A Short Review. CLEAN - Soil, Air, Water, 47(1), 1700653. https://doi.org/10.1002/clen.201700653. 
Research, Society and Development, v. 11, n. 1, e6811121720, 2022

(CC BY 4.0) | ISSN 2525-3409 | DOI: http://dx.doi.org/10.33448/rsd-v11i1.21720

Yin, F., Dong, H., Zhang, W., Zhu, Z., \& Shang, B. (2018). Antibiotic degradation and microbial community structures during acidification and methanogenesis of swine manure containing chlortetracycline or oxytetracycline. Bioresource Technology, 250, 247-255. https://doi.org/10.1016/j.biortech.2017.11.015.

Zhang, H., Jin, Z., Han, L., \& Qin, C. (2006). Synthesis of nanoscale zero-valent iron supported on exfoliated graphite for removal of nitrate. Transactions of Nonferrous Metals Society of China, 16, s345-s349. https://doi.org/10.1016/S1003-6326(06)60207-0.

Zhang, Y., Zhang, Z., Suzuki, K., \& Maekawa, T. (2003). Uptake and mass balance of trace metals for methane producing bacteria. Biomass and Bioenergy, 25(4), 427-433. https://doi.org/10.1016/S0961-9534(03)00012-6. 